\title{
Historical Frontiers and the Rise of Inequality. The Case of the Frontier of Granada
}

\author{
Daniel Oto-Peralías \& Diego Romero-Ávila \\ St Andrews University, Pablo de Olavide University \\ Accepted for publication at the Journal of the European Economic Association
}

\begin{abstract}
This paper explores the political economy that leads frontier regions to be unequal. By focusing on the presence of a stable frontier between Castile and the Nasrid Kingdom of Granada in the late Middle Ages, our analysis shows how a historical border may generate differences in inequality that can become extremely persistent. We argue that the dynamics of being a militarily insecure frontier region created the conditions on the Castilian side for a high concentration of economic and political power. Through the application of a border specification and a spatial regression discontinuity design to municipal-level data, we find that municipalities on the Castilian side have a significantly higher percentage of landless workers, a greater accumulation of wealth, and more jurisdictional rights among the privileged orders, as measured in the eighteenth century. We use current indicators of land inequality and development to show that the effect of the frontier of Granada persists even today.
\end{abstract}

Keywords: Historical Frontiers, Political Power, Political and Economic Inequality, Spanish Reconquest, Frontier of Granada, Spatial Regression Discontinuity Analysis.

JEL Classification: C14, N2, N9, O1

Corresponding Author: Diego Romero-Ávila, Pablo de Olavide University, Department of Economics, Ctra de Utrera, Km. 1, Sevilla, Spain. E-mail: dromtor@upo.es. Tel. (+34) 954 348381. Fax: (+34) 954349339.

Daniel Oto-Peralías. University of St Andrews, School of Management, Centre for Responsible Banking \& Finance. The Gateway, North Haugh, St Andrews, Fife, KY16 9AJ, UK. E-mail: dop2@st-andrews.ac.uk.

Acknowledgements: The authors are particularly indebted to Nicola Gennaioli (the Editor) and three anonymous referees of this Journal for valuable comments and suggestions that led to a substantial improvement of the original manuscript. We also thank Luis Ángeles, Jesús Crespo-Cuaresma, John O.S. Wilson, Simon Wren-Lewis, and participants at the 2015 Royal Economic Society Meeting held in Manchester, the Norwegian School of Economics, Glasgow University, Halle Institute for Economic Research, Sheffield University, Pablo de Olavide University, and Vienna University of Economics and Business for valuable comments and suggestions. Thanks also go to archival staff of the Provincial Historic Archive of Seville for helping us with the access to some of the data employed in the article. The authors acknowledge financial support from the Spanish Ministry of Science and Technology through grant 
ECO2009-13357, the Spanish Ministry of Economics and Competitiveness through grant ECO2012-35430 and the Andalusian Council of Innovation and Science under Excellence Project SEJ-4546.

\section{Introduction}

Frontiers have largely shaped the economic geography of many regions and countries throughout the world. ${ }^{1}$ Despite the importance of frontiers in history, few studies have dealt empirically with this issue. This paper aims to explore the political-economic effects that can lead frontier regions to be unequal. We argue that frontiers can adversely affect the path of development of societies by leading to an excessive concentration of power in the hands of the elites. Our hypothesis is that, in the presence of a military threat, frontiers must be defended and this fact biases the political equilibrium in favor of the military elite, which ends up accumulating an enormous amount of economic and political power. We empirically test this hypothesis by exploiting the existence of a stable frontier between Castile and the Nasrid Kingdom of Granada in the late Middle Ages in the southern Spanish region of Andalusia. Our results indicate that the frontier of Granada had very persistent effects on political and economic inequality, which decisively affected subsequent development.

Historically, with the possible exception of the U.S. frontier, which involved individualism, selfgoverning forms of political democracy, and aversion to social stratification (Turner, 1920), frontiers have been associated with political and economic inequality. For instance, Hennessy (1978, p. 26) asserts that "far from stimulating democratic values and creating a democratic myth, the frontier in Latin America has bred a spirit of lawless anarchy and perpetuated outworn forms of social and economic organization [...]. It could be argued that it is these frontier regions which have bred caudillismo or strong man rule; that power and prestige derive from ownership of land and domination over a serf-like rural following". Other frontiers, such as those of the Boers in South Africa, the Russians on the European side and in Siberia, or the German expansion into the region East of the Elbe, did not introduce significant political institutions providing serious fundaments for a modern state.

\footnotetext{
${ }^{1}$ There are frontiers not only in the colonization of the New World (e.g., North and South America) -Turner (1920) and Gerhard (1959)- but also in the Old World. Examples of the latter are Hadrian's Wall, which delimited the northern limits of the Roman Britain, the Great Wall separating the settled Han Chinese from the nomadic tribes of the North for over two millennia, the Arab-Byzantine frontier in the Middle Ages, the frontier that separated Western Europe from alAndalus during the Christian re-occupation of the Iberian Peninsula, the so-called Reconquista, the border between the Habsburg and Ottoman Empires in Eastern Europe, Russian expansion in Central Asia, and Germany's expansion eastward, to name just a few. See (supplementary) Appendix A for a more detailed account of frontiers of settlement and defense throughout history.
} 
Until now, the only empirical study that deals explicitly with the political economy that leads frontiers to be unequal is García-Jimeno and Robinson (2011). According to their conditional frontier hypothesis, the contrasting outcomes obtained from the different frontier experiences on the American continent must be sought in the initial political equilibrium existing in society at the time of the frontier's expansion. When the political equilibrium was biased toward the oligarchies with political power, as occurred in most of Latin America, frontier land was allocated on an inegalitarian basis favoring members of the political elite to ensure they remained in power. Closely related is the existing literature that links the emergence of institutions to frontier experiences. This includes the prevalence of extractive institutions that took the form of serfdom in the region East of the Elbe due to a certain configuration of social institutions biased towards the landowning elite at the expense of the peasant class, as postulated by Brenner (1976). ${ }^{2}$ More generally, Acemoglu and Robinson (2012) and Chaney and Hornbeck (2015) hold the view that in pre-industrial times large adverse shocks leading to persistent labor scarcity created a critical juncture in history that, depending on the initial balance of power in society, pushed institutions in the direction of either strengthening pre-existing extractive institutional arrangements (as in Eastern Europe) or of weakening them (as in much of Western Europe), with feudalism eventually disappearing. ${ }^{3}$

This article opens a new research avenue on the political-economic effects associated with historical frontiers. We establish the hypothesis that militarily insecure frontier regions, because of their defense needs, favor a political equilibrium biased toward the elite groups, which generates political and economic inequality, thus undermining subsequent economic development. The frontier of Granada, which was for two and a half centuries the frontier in Europe between Christianity and Islam, constitutes an excellent opportunity to test this hypothesis. It allows us to compare municipalities that were conquered and resettled under the influence of an insecure frontier, on the Castilian side, with municipalities that were organized and repopulated after the dismantlement of the frontier, on the Granada side. ${ }^{4}$ On the one hand, the Castilian part was organized and resettled under the premises of being an insecure frontier region facing the Muslim adversary, which

\footnotetext{
${ }^{2}$ In a similar spirit, Gerhard (1959, p. 223) argues that medieval frontiers such as that of the Eastern colonization were associated with the migration of the medieval feudal organization in full. Due to space considerations, other arguments and references on the Brenner debate are provided in Appendix B.

${ }^{3}$ With a focus on African societies, Fenske's $(2012,2013)$ land abundance view of African history links the existence of open frontiers in Africa, characterized by large tracts of unoccupied land and low population density (and in turn labor scarcity), to a lack of price and rights over the land, as well as to the prevalence of slavery and other forms of coerced labor across the African continent.

${ }^{4}$ The Castilian side of the frontier approximately encompasses the modern provinces of Cadiz, Cordoba, Huelva, Jaen, and Seville, while the Granada side the provinces of Malaga, Granada and Almeria.
} 
decisively affected the way the resettlement was done. As illustrated in Figure 1, this created the conditions for a specific configuration of de facto and de jure political power distribution in favor of the powerful groups (particularly the nobility, the Church, and military orders), which generated extractive institutions to exploit the landless peasantry, with negative consequences that persisted over time right through to the twentieth century. ${ }^{5}$ More specifically, the need to defend against the enemy led the nobility and military orders to play a central role in the occupation and protection of the new territory. This political equilibrium biased towards the privileged orders brought about a high concentration of de facto political power in the form of great land allocations and de jure political power through jurisdictional rights along the frontier. Other factors such as the insecurity of a border area constantly under threat promoted a type of extensive land exploitation based on pasture and livestock, and the low population density - a consequence of this insecurity- was also conducive to the accumulation of land in a few hands. On the other hand, the former Nasrid Kingdom of Granada evolved differently, largely because once it had been conquered, the phenomenon of the frontier ceased to exist, and the Muslim opponent was no longer a threat. The territory could be repopulated and organized according to different premises and objectives, and the distribution of land ended up being relatively more egalitarian.

\section{[Insert Figure 1 about here]}

The empirical strategy is operationalized by exploiting municipality-level data to study the effect of the frontier of Granada on the concentration of economic and political power on the Castilian side. We compile historical data for the 771 municipalities making up modern-day Andalusia. Our dataset covers the percentage of landless workers over the total agrarian active population in 1787 -which is closely related to the extent of land concentration in the hands of the privileged orders- and the amount of income earned by the wealthiest individual in each city or village in the 1750 s, as measures of de facto political power. As a measure of de jure political power, we employ the jurisdictional category of each municipality under the Ancien Regime, i.e. those cities and villages over which nobles, military orders and the Church had jurisdictional rights in 1787 . We also collect data on current land inequality and development outcomes, and many geographic and historical controls. We then compare observations on both sides of the frontier using a border specification and a semiparametric spatial regression discontinuity design (RDD). The evidence shows that the

\footnotetext{
${ }^{5}$ According to Acemoglu and Robinson (2010, p. 8), "de jure political power refers to power that originates from the political institutions in society [... and] de facto political power originates from the ability of the group in question to solve its collective action problem and from the economic resources available to the group (which determines their capacity to use force [and influence] against other groups)".
} 
municipalities on the Castilian side have a significantly higher percentage of landless workers, a higher level of accumulated wealth, and more jurisdictional rights in the hands of the privileged orders, whereas there are no significant discontinuous shifts across the frontier in a wide array of climatic and geographic factors, or in pre-existing conditions. In addition, using current indicators of land inequality measured in the 1980s, we show that the effect of the frontier of Granada persists today, five centuries after it disappeared. These results are robust to controlling for a wide array of observable characteristics and employing alternative specifications in the RDD, using microdata for a sample of almost 129,000 holdings, as well as to a series of falsification tests consisting in either drawing 1,000 random placebo borders or moving the true frontier northwestward and northward. Using several outcomes linked to contemporary development, we corroborate Acemoglu and Robinson's (2006, 2010) view that historical structural inequality is harmful to economic development.

Our findings on the negative consequences that the frontier of Granada had for the border region of Andalusia are consistent with the "conditional frontier thesis" proposed by García-Jimeno and Robinson (2011). ${ }^{6}$ For the case of the Castilian expansion into southern Spain in the thirteenth century, the dynamics of a frontier region with a threatening enemy favored the control of land and political power by the nobility. Thus, the frontier of Granada is an instance of a more general phenomenon: a frontier that leads to pernicious effects due to a political equilibrium defined by a high concentration of power in the hands of a military elite, which is reinforced by the fact of being an insecure border region. Our results may be applicable to other insecure frontier regions. ${ }^{7}$

Our study differs in several respects from others analyzing historical borders since it focuses on the political economy that leads frontiers to be unequal. As such, it primarily centers on the immediate effects of being a frontier on inequality, and secondarily, it documents the long-term persistence of the effects. Also, the case of the frontier of Granada is more extreme: the frontier ceased to exist at

\footnotetext{
${ }^{6}$ Their analysis of the frontiers on the American continent points to the existence of higher long-run economic growth and current democracy levels, the greater the constraints on the executive in 1850 and the longer the frontier.

${ }^{7}$ While García-Jimeno and Robinson (2011) paint a story in which the central oligarchy wants its affiliates to control frontier regions -which is a resource that is used to ensure the oligarchic elites cement themselves in power-, Hennessy (1978) emphasizes the fact that the center finds it hard to control frontier land and this empowers local strongmen to amass huge power. In either case, the existence of a frontier favors the perpetuation in power of the nondemocratic oligarchy, rather than create a viable rural middle class comparable with that in North America. In principle, both mechanisms would be compatible with our findings. However, our historical account seems to favor the former hypothesis, though placing more emphasis on the center's final objective of strengthening frontier positions and preventing foreign conquest.
} 
the end of the fifteenth century, but its effects are still felt five centuries later. ${ }^{8}$ Finally, this article also contributes to the literature on the long-term persistence of historical events by shedding light on the causes of the long-standing inequality that Andalusia has suffered throughout its modern history. ${ }^{9}$ This issue has been emphasized, among others, by Vicens Vives (1969) who pointed out that along the frontier of Granada the large landholdings of the military orders and the greatest noble families were consolidated to such an extent that all the nobles that have played an important role in Spanish history since the fifteenth century have based their power on this latifundia system. This initial concentration of economic and political power persisted over time, stamping on Andalusia its hallmark of "the classic land of the latifundia or slave-worked estates" (Brenan, 1950, p. 114) and caciquismo (Ortega López 1986; Tusell 1976).

The remainder of the paper is organized as follows: Section 2 provides a historical overview. Section 3 describes the data, and Section 4 provides preliminary statistical evidence on the effect of the frontier of Granada. Section 5 develops the empirical strategy and presents the empirical evidence from the estimation of a border specification and a spatial RDD, and also conducts several robustness checks. Section 6 presents an RDD applied to microdata of agricultural holdings. Section 7 investigates the effect of the Granada frontier on several contemporary development outcomes. Section 8 puts forward some implications and concludes.

\section{Historical Background}

\subsection{The Frontier of Granada and the Origins of Economic and Political Power Concentration in}

\section{Andalusia}

The Reconquista is modern Spain's historical constitutive process. Over a protracted period of almost eight hundred years (from approximately 722 to 1492), the Christians located in the north

\footnotetext{
${ }^{8}$ The extant literature has mainly focused on historical borders (see, among others, Dell, 2010; Grosjean, 2011a, b; Becker et al., 2015). Borders can be conceptualized as a geographical delimitation (a line) separating two political or administrative units. Historical and modern borders may be very useful to exploit discontinuities (for example in institutions). By contrast, frontiers are a different phenomenon. They represent large geographic areas delimiting major cultural and political blocks, under military insecurity and instability, and with a potential for further territorial expansion. Frontiers develop specific and differentiated cultural, political and economic patterns, giving rise to "frontier societies". In this sense, our paper is original because it focuses on the dynamics of a frontier society.

${ }^{9}$ This line of research pioneered by the seminal papers by Engerman and Sokoloff (1997) and Acemoglu, Johnson, and Robinson (2001) focusing on European colonialism has been followed by a number of different studies investigating historical events such as overseas colonialism, revolutions, or religious reformations. They include, among others, Banerjee and Iyer (2005), Gennaioli and Rainer (2007), Acemoglu et al. (2008), Becker and Woessmann (2009), Gallego (2010), Iyer (2010), Bai and Kung (2011), Bruhn and Gallego (2012), Chaney (2013), Fenske (2014), OtoPeralías and Romero-Ávila (2014a), Bai and Kung (2015), Cantoni (2015), and Chaney and Hornbeck (2015).
} 
gradually conquered the Muslim territory to the south and implemented measures to colonize these new lands. These measures, aimed at organizing and resettling the conquered territory, were fundamental to the subsequent development of each region (Oto-Peralías and Romero-Ávila, 2014b). After the battle of Las Navas de Tolosa in 1212, most of the southern third of the peninsula suddenly fell into Christian hands. The rapid advance of the Christian frontier made it difficult for the Crown to officially organize the repopulation on such a large scale and altered the balance of power toward the nobility and military orders, who were required for conducting an effective occupation and defense of the new lands. Within this context, the fact that the Reconquista was not fully completed, due to the resistance of the Nasrid Kingdom of Granada, was a factor that decisively influenced the repopulation of Andalusia, which was a frontier region for two and a half centuries. The insecurity derived from the existence of the frontier determined the organization of the new lands by further strengthening the power position of the privileged groups.

In the first place, the continuous warfare between Castile and the Kingdom of Granada forced the former to make new and important military efforts and reinforce the frontier of Granada, particularly after the uprising of the mudéjares in 1264 and over the decade following the first incursion of the Marinids in 1275. To this end, Alfonso X called on the military orders to do their duty of defending the frontier. However, by the end of the thirteenth century the military orders had lost interest in frontier warfare and were concentrating on administrating their enormous wealth. ${ }^{10}$ As a result, from this point onwards the task of defending and protecting the frontier territories was entrusted to the great noble families of the region. The frontier was able to fulfill the needs of both the Crown and the nobles. The former secured frontier positions that were difficult to defend and were at constant risk, while the latter found in the frontier a means of social, economic, and political empowerment (Cabrera Muñoz 2006).

Secondly, the low population density that is characteristic of these insecure border regions, the demographic decline brought about by epidemics, ${ }^{11}$ and the expulsion of the Muslim population

\footnotetext{
${ }^{10}$ Following the example of the Holy Land crusaders, the Castilians created three great military orders that served as armies for the country to conquer Muslim lands and defend the Christian frontier. The order of Calatrava was founded in 1158, the order of Santiago in 1170, and the order of Alcántara in 1175, during the second half of the twelfth century, a period from which military orders grew in importance due to their key role in the defense of the frontier (Forey, 1984; González Jiménez 1989), with the creation about a century later of the order of Santa María de España (1272). Besides their military activity, these orders played an active role in the resettlement of the conquered lands.

${ }^{11}$ Due to lack of data, we are unable to control for the number of casualties that the Black Death caused on each side of the frontier. However, we can conjecture that the Black Death is likely not to be the explanation for the frontier effect found below given that the pest equally acted on both sides of the frontier, as the disease could easily spread across borders.
} 
after the 1264 revolt, all favored the establishment of an extensive agricultural system based on large estates, which were concentrated in the hands of the nobility. ${ }^{12}$ Thus, the intensive agriculture that had previously prevailed in the Guadalquivir Valley since Roman times was replaced by an extensive agrarian sector dominated by olive groves and sheep (Vicens Vives 1969; Malefakis 1970). Thirdly, key to the expansion of the seigneurial system and the consolidation of the high nobility in Andalusia after the defeat of Peter I was the founding of the Trastamaran dynasty (13691504) in favor of Henry II. The new dynasty again converted the nobility into the main player in the defense of the frontier and, accordingly, handed out extensive lordships and land allocations. Fourthly, the relative weakness of the Crown vis-à-vis the high nobility, who controlled town council positions, facilitated the increase of nobles' lands through usurpations (Cabrera Muñoz 1989).

In short, all the above factors biased the political equilibrium toward the nobility at the expense of the peasantry. The former enjoyed enormous political power in the form of jurisdictional rights, which provided the legal and political apparatus that afforded them de jure political power over the broad mass of the population. This implied the attachment of the landless peasantry to the land of landowners -who had to provide the latter with labor services- and the control of the judiciary and the local council by the nobility. This de jure political power in combination with de facto political power afforded by the high concentration of land allowed the landed elite to set economic institutions to their own benefit. Examples are the existence of severe restrictions on land and grain transactions, labor contracts with caps on agricultural wages, land tenure systems implying shortterm leases, and the obligation to use the nobles' mill to grind grain and press olives. Nobles also exploited monopoly rights over public ovens, butcheries, forges, wineries, taverns, and potteries (Cabrera Muñoz 2006). They were often granted the right of taxation at local level, and they adjudicated over disputes about property, punishing minor crimes and even imposing death sentences for capital crimes (Dewald 2004). They could also use their power to buy and control state offices (Truxillo 2001).

\footnotetext{
${ }^{12}$ Cabrera Muñoz (2006) argues that adverse population shocks like the failure of the initial repartimientos, the expulsion of the Muslim population and epidemics contributed to the expansion of lordships which served as a way to compensate the nobility for the losses incurred and as a means to occupy and repopulate large tracts of depopulated territories. This has some similarities to the strengthening of feudal links through serfdom in Eastern Europe coinciding with the demographic crisis of the late fourteenth century (Brenner, 1976). In the context of the expulsion of 120,000 Moriscos from the Kingdom of Valencia in 1609, Chaney and Hornbeck (2015) argue that the relative land abundance and labor scarcity in former Morisco districts brought an institutional response that, instead of empowering peasants by improving their outside options -as would be expected by the neo-Malthusian view of feudal decline by Postan (1973) and Le Roy Ladurie (1977)-, led to coordinated efforts by the powerful elites to coerce the peasantry -in a similar spirit to Brenner's account of the second serfdom. These facts can be reconciled under the theoretical framework of Acemoglu and Wolitzky (2011).
} 


\subsection{Was Economic and Political Power Concentration Second-best?}

An interesting question is whether the resulting strategy of colonizing border regions through large lordships controlled by the privileged orders could potentially be second-best, and whether there was an alternative way to settle these territories that had less nefarious consequences. The answer is that there probably was. Indeed, according to González Jiménez (1981a) and Cabrera Muñoz (2006), after Ferdinand III's conquest of the lands of Cordoba (1236), Jaen (1246), and Seville (1248), the Crown initially tried to implement a system of military occupation in Andalusia that allowed the Muslim population to stay in the conquered territory, since it constituted an abundant labor force and a stable source of fiscal revenues. A similar "colonial" system had been established in Valencia and Murcia (Burns, 1976). In addition, the Crown was initially reluctant to employ the nobility and military orders as the main guarantor of the occupation and defense of the conquered areas, given the excessive concentration of power they accumulated in central Spain (Extremadura and La Mancha). Ferdinand III and Alfonso X therefore conducted a repopulation process that sought to attract the maximum number of settlers who, by obtaining property rights over the lands and dwellings obtained in the repartimientos, would occupy and defend the territory from the enemy. This is the reason initially large estates and lordships had limited importance (Cabrera Muñoz, 1989).

However, the repopulation process based on small and medium-size holdings of free peasants came to a halt due to the mudéjar crisis in 1264 that brought about extreme rural depopulation, the incursion of the Marinids over the 1275-1285 period, and the continuous frontier wars that would last until 1350, which forced Christian settlers to concentrate in urban centers that afforded military protection. Despite the fiscal exemptions offered to attract settlers to the frontier, a lack of manpower was still evident in the fourteenth century (González Jiménez, 1981b). In this context of frontier insecurity, Castilian monarchs had no choice but to delegate military and governmental powers to the nobility and their lordships. As will be shown in the empirical analysis, these inevitable patterns of conditional settlement would bring about negative long-term consequences in the distribution of economic and political power, which are still visible even today.

The former Nasrid Kingdom of Granada evolved differently, largely because once reconquered the phenomenon of the frontier ceased to exist, and Castile's enemy was no longer a threat. The repopulation and organization of the territory could be made under different premises and objectives. Accordingly, although nobles also received generous land allocations, its distribution ended up being relatively more egalitarian, and the nobility received fewer jurisdictional rights. By 
the late fifteenth century, the Catholic Monarchs had accumulated enough power to control the nobles' pre-eminence (Vicens Vives 1969). This was aimed at preserving the existing balance of power among the main noble lineages, and between these lineages and the Crown. Hence, once the frontier ceased to exist, the position of the Crown was strengthened. ${ }^{13}$ In sum, we can exploit the discontinuity produced by the frontier; on the Castilian side, the resettlement was conducted under the circumstances of an insecure frontier region, while on the Granada side, the organization of the new land was carried out in relative safety.

\subsection{The Persistent Concentration of Economic and Political Power and its Implications}

Once the point of departure had been established, several mechanisms of persistence perpetuated and even aggravated the initial level of inequality. One key factor was the proliferation of entailed estates protected by law (mayorazgos) and other regulations by which land became non-conveyable such as the communal lands of municipalities and ecclesiastical land in mortmain. In addition, jurisdictional rights were hereditary, which guaranteed the persistence in the concentration of disproportionate shares of de jure political power in the hands of the nobility. The nineteenth century witnessed two major developments that failed to shift the balance of power in favor of the landless working class. First, several liberal reforms dismantled the legal apparatus of the Old Regime, but many jurisdictional domains became the property of the nobles in charge of the jurisdiction (Ruiz-Maya 1979). Second, in the process involving the disentailment of communal and ecclesiastical landownership, known as desamortización, the financial needs of the state prevailed, and land was bought up by the rich, the bourgeoisie and the aristocracy (Carrión, 1975). This ensured the continuation of the previous economic institutions, since the oligarchic structure of the Ancien Regime remained fairly unaltered. Far from disappearing, the unfavorable situation for the landless peasantry endured until well into the twentieth century, thereby contributing to the outbreak of the Civil War in 1936-1939 (Brenan 1950). The situation did not improve during the early years of General Franco's regime (1939-1952), in which the strict control of prices and supply in the markets for goods and factors led to limited factor mobility. ${ }^{14}$

\footnotetext{
${ }^{13}$ It is well known in Spanish historiography that nobles and military orders were a competing power against the Crown, rather than a simple intermediary between the Crown and the populace. Indeed, before the conquest of Granada, due to the Crown's dependence on the nobility to protect the frontier, the latter used their power to transform royal jurisdictions into noble jurisdictions (Rodríguez Molina 2000).

${ }^{14}$ No major agrarian reform was conducted over the postwar period, with the "agrarian question" being partly resolved thanks to the rural exodus, either to the cities or to the industrialized regions of Spain or Europe (Caro Baroja, 1966). Despite Spain's integration into the European Union and the associated redistributive policies, a fall in regional disparities has not been observed since the eighties.
} 
Regarding the implications for economic development, high land concentration had negative consequences for agricultural productivity, as highlighted by the enlightened thinkers of the eighteenth century (Olavide 1768; Jovellanos 1795). It is also argued that the agricultural population's low standard of living and lack of purchasing power has been a major factor responsible for the failure to industrialize in Andalusia (Nadal 1975; Nadal, Carreras and Sudriá 1987). ${ }^{15}$ Oto-Peralías and Romero-Ávila (2014b) hold the view that under such conditions, broad segments of the population were excluded from participating in economic activity when the opportunity to industrialize arrived. As a result, regions with large estates fell behind during the industrialization period.

\section{Data Description}

We have compiled a dataset for the 771 municipalities there are in Andalusia. It contains one indicator measuring whether the town or village belonged to the Castilian part of Andalusia, three variables related to historical measures of land concentration, wealth accumulation, and jurisdictional rights, two variables related to current measures of land inequality, several outcomes linked to contemporary economic development, and a wide array of variables associated with climatic and geographic factors. To begin with, the frontier of Granada is defined as it was at the beginning of the War of Granada (1481-1492), which coincides with the subsequent boundaries of the historical province of Granada. Since the end of the great conquests of Ferdinand III and Alfonso $\mathrm{X}$ in the mid-thirteenth century, the borders of the Kingdom of Granada were quite stable, and only some territories were lost near the Strait of Gibraltar and around the area of the town of Antequera (Mestre Campi and Sabaté 1998). ${ }^{16}$ Since this paper's hypothesis is that the existence of a frontier with an enemy was an important factor in the organization and repopulation of the territory, we prefer to use the 1481 frontier, i.e., the last line that could affect the repopulation of the Christian territories. Arguably, once the War of Granada began, the new lands conquered during the war could be organized and resettled according to different purposes. In statistical terms, our treatment group will include those municipalities that have been exposed to frontier at some point in time; that is,

\footnotetext{
${ }^{15}$ This would agree with Brenner's $(1976,1982)$ view that East of the Elbe it was easier for the landlord to squeeze the peasantry rather than invest in agricultural development, as in England. This in turn prevented the emergence of a domestic market for manufactured goods and an industrial labor force.

${ }^{16}$ Over the fourteenth century and most of the fifteenth century, the Castilians annexed only a few locations along the frontier, i.e., Teba, Pruna, and Olvera (1327-1330), Alcalá la Real (1341), Antequera (1410), Castellar and Jimena (1431-1434), Huelma and Bélmez (1438-1448) and Archidona (1462), in addition to Algeciras (1344) and Gibraltar (1462) on the Atlantic coast, which also served as a natural frontier with North Africa (see Mestre-Campi and Sabaté 1998, for more details). These conquests were therefore local in nature and constituted relatively small adjustments of the frontier established in the thirteenth century (González Jiménez 2006).
} 
those municipalities that have at some stage been part of the Castilian side of the frontier. Otherwise, an earlier definition of the frontier would make some treated municipalities appear in the control group. Thus, we take the border in its maximum extension, although for robustness purposes we also look at various expansion stages below.

Regarding the historical measure of land concentration, we use the percentage of landless workers over the total active agricultural population in 1787, as recorded by the Floridablanca census. The total agricultural population is composed of farmers and landless day laborers. The percentage of landless workers can be considered as a proxy for historical structural inequality. This is referred to as a type of inequality that is historical in the sense that it has strongly persisted over centuries, and structural in the sense that it is a class-based inequality. Figure 2 shows the percentage of landless workers for each municipality. Although the values are very high almost across the board, the Castilian part of Andalusia has a higher percentage of landless workers (87\%), versus $72 \%$ in the former Kingdom of Granada.

Concerning the historical measure of wealth accumulation, we use the total amount of income earned by the individual earning the most in each municipality. This variable is provided by the Catastro de Ensenada compiled between 1750 and 1753, and more precisely, by a series of books known as El Mayor Hacendado. Given the economic structure of that period, with a clear predominance of agriculture, in the vast majority of cases the mayor hacendado (i.e., the individual with the highest income) is a landowner, and the bulk of the income comes from land (Artola, Bernal, and Contreras, 1978). Since this indicator of wealth accumulation can vary depending on the municipality's extension, we express it relative to the size of the municipality. Figure 3 shows remarkable differences between the Castilian part of Andalusia and Granada. The average value for the former is about 1,550 reales $/ \mathrm{km}^{2}$, while for the latter it is about 674 reales $/ \mathrm{km}^{2}{ }^{17}$ The former two variables can be thought of as measures of de facto political power.

Our third historical variable refers to jurisdictional rights in the Ancien Regime. We use data from the 1787 Floridablanca census, which identifies each municipality's jurisdictional category. There are four types of jurisdictions: municipalities owned directly by the Crown (realengo or royal jurisdiction), ecclesiastical lordships, noble lordships, and military order lordships. ${ }^{18}$ Since we are

\footnotetext{
${ }^{17}$ In the empirical analysis, we control for other factors that can also be related to income, such as land quality.

${ }^{18}$ By far the most important categories are realengos, accounting for $45 \%$ of the municipalities, and noble lordships, representing 49\%. However, in terms of population, to the extent that the main towns were under royal jurisdiction, municipalities depending on the Crown represented $59 \%$ of the total population, while $37 \%$ were under noble
} 
interested in a measure of the (de jure) political power of the privileged orders, we use a single group to consider those jurisdictions depending on the nobility, military orders, and the Church while keeping in mind that municipalities belonging to the latter two groups were residual in Andalusia (only 28 and 12, respectively). Figure 4 depicts the distribution of jurisdictions in Andalusia. There is a noteworthy presence of jurisdictions belonging to the privileged orders along the frontier of Granada, particularly in the southwestern and central parts.

\section{[Insert Figures 2-4 about here]}

In sum, these three historical variables can be interpreted as measures of the concentration of political power in the hands of the privileged orders versus the peasantry. In addition, we also calculate two indicators of current land inequality using the agricultural census of 1982 in order to analyze whether the effect of the frontier of Granada on inequality has persisted over time, and if there is still an effect in the second half of the twentieth century. These variables are the percentage of utilized agricultural area (UAA) in holdings with 200 hectares or more of UAA, and the Gini coefficient of UAA. We consider private agricultural holdings (owned by private persons or legal entities). ${ }^{19}$ To save space, the definitions and sources of the remaining variables are presented in Table A1, while the descriptive statistics are reported in Appendix D.

\section{Preliminary Evidence}

On the basis of the historical account presented in Section 2, our hypothesis is that the frontier of Granada was a factor that significantly increased political and economic inequality on the Castilian side of Andalusia, but not in the territory of the Kingdom of Granada. We test our hypothesis by comparing municipalities on both sides of the frontier. As a first approximation, Table 1 (Panel A) presents tests of mean differences for our three historical indicators related to economic and political power concentration. Conley (1999) standard errors robust to spatial correlation of unknown form are used. ${ }^{20}$ The first three columns show the results for the whole sample. The average value of the percentage of landless workers in 1787 is higher in the Castilian part of Andalusia than in Granada, with the difference being highly significant. The accumulation of income as given by the variable Mayor Hacendado's income over land area is also significantly higher in the former territory of Castile. As regards the jurisdiction of privileged orders (measured with a dummy variable), its

jurisdiction. In terms of surface area, royal jurisdiction accounted for $49 \%$ of the total land area, with the figure for noble jurisdictions being $45 \%$.

${ }^{19}$ See Figures A1 and A2 in Appendix C for maps showing the distribution of these two variables.

${ }^{20}$ We employ cutoffs of 1 decimal degree, beyond which the spatial correlation is assumed to be zero. 
average represents the percentage of cities and villages governed in this way. Again, this percentage is significantly higher (by almost 23 points) on the Castilian side of Andalusia. In columns 4-6 in Table 1, we compare municipalities whose centroids are within 50 kilometers of the frontier (i.e., we set a bandwidth of $100 \mathrm{~km}$ ), and columns 7-9 restrict the sample to municipalities within 25 kilometers of the frontier. Although this now involves comparing municipalities that are closer to the frontier and hence more alike in geography and climate, the mean differences in each one of the three relevant variables between both sides of the frontier remain fairly unaltered and statistically significant. $^{21}$

Panel B in Table 1 investigates whether the effect of the frontier of Granada on inequality still remains today, five centuries after it disappeared. Towards that end, we use the two indicators of land inequality calculated with the 1982 agricultural census, namely, the percentage of UAA in holdings $\geq 200$ hectares and the Gini coefficient. The results indicate that land concentration is higher in the Castilian part of Andalusia than in the former Kingdom of Granada, with mean differences being highly significant in the three samples. It is remarkable that when focusing on municipalities within 25 kilometers of the frontier, even today we can still observe differences between both sides of the border. This implies the presence of extraordinary persistence in inequality over the centuries, and this is so despite the attenuating effects due to spatial integration. ${ }^{22}$

[Insert Table 1 about here]

\section{Econometric Approach}

Although the initial evidence from the analysis of mean differences is appealing, it may be plagued by omitted variables bias. For example, factors related to geographic and climatic conditions left uncontrolled or unobservable characteristics may differ on both sides of the frontier, and influence positively the concentration of land on the Castilian side, thus creating an upward bias in the treatment effect. In dealing with the bias caused by omitted observables we include a wide range of geographic and climatic characteristics, whereas unobservable heterogeneity is handled through a twofold strategy. First, we estimate a border specification that compares municipalities within a 25 -

\footnotetext{
${ }^{21}$ Figure A3 in Appendix E depicts the sample of municipalities studied in each case.

${ }^{22}$ Spatial integration may act against our hypothesis that there are significant differences in economic and political power concentration across the frontier when we narrow the sample down to observations close to the border, especially when the frontier ceased to exist at the end of the fifteenth century, and our dependent variables correspond to the eighteenth century. It is possible that during that period, social and economic factors on one side of the former frontier affected municipalities on the other side. For example, a village in which the initial level of land concentration was high may have increased the level of land concentration in its neighbors if landowners from that village expanded their large estates by purchasing land in neighboring villages.
} 
kilometer strip on either side of the frontier of Granada in order to determine the statistically significant average treatment effect. By limiting the analysis to the area $25 \mathrm{~km}$ from the frontier, one implicitly assumes that any set of unobservable confounders is relatively unimportant when looking at the subset of data close to the threshold. Second, we apply a spatial RDD in order to shed more light on the causal effect of the frontier of Granada on the five outcomes considered. This is aimed at identifying a spatial pattern of economic and political power concentration by showing discontinuous jumps in the frontier for a sample of municipalities falling within 25 kilometers on each side of it. The focus on this restricted sample can be considered as the most rigorous way to test our hypothesis and provides a sufficiently good fit to the polynomials in our forcing variables. ${ }^{23}$ In addition to spatial integration, the possibility that power concentration was prevalent on both sides of the frontier may also attenuate any differences in power concentration, ${ }^{24}$ thus creating a downward bias in the treatment effect. To the extent that observed and unobserved heterogeneity are properly accounted for in the empirical analysis, our estimates of the treatment effect can be taken as a lower bound of the true effect.

\subsection{Testing for Geographic, Climatic and Preexisting Differences across the Frontier}

The validity of the border specification, and particularly of the spatial RDD, requires all the relevant factors besides the treatment to vary smoothly at the Granada frontier, and as such there cannot be any discontinuous jumps in any of these features. We test the existence of statistically significant differences across both sides of the border in the following geographic and climatic dimensions: altitude, ruggedness, terrain with a steep slope, direct access to the sea, rainfall, temperature, aridity, and Mediterranean phytoclimate. We also test for cross-border differences in soil quality and in several soil dimensions, such as moderate or high erodibility, low topsoil carbon, and fine soil texture, as well as in the proportion of arable land, and the percentage of land devoted to herbaceous crops. As shown in Panel A of Table 2, it is worth noting that there are no statistically significant jumps at the frontier of Granada in any of the eight climatic and geographic features considered. Likewise, Panel B discards the existence of cross-border differences in soil quality, soil characteristics, percentage of arable land, or the type of crops.

\footnotetext{
${ }^{23}$ We follow Becker et al. (2015), who recommend the use of this twofold strategy for settings of treatment effects of long-gone borders. This is because in a setting with sharp spatial discontinuities in treatment, the spatial RDD identifies more cleanly (than the border specification) any short-term treatment effects, but is also subject to attenuation bias due to diffusion and interaction effects across the frontier in settings of long-term effects of historical borders that ceased to exist in the distant past.

${ }^{24}$ See Section 5.5 for a detailed account of the existence of a relatively high power concentration on the Muslim side of the frontier (though lower than on the Castilian side).
} 
Finally, it is necessary to discard the possibility that differences between the two sides of the border were in place before the formation of the frontier. Accordingly, we check for the existence of discontinuous jumps in the presence of Roman roads, distance to urban centers in 1200 and 1400, and in pre-Christian land uses in al-Andalus between the tenth and twelfth centuries measured through the percentage of surface area in each municipality made up of forest, pastureland, intensive agriculture, and non-intensive agriculture. The evidence, reported in Panel C, does not support the existence of statistically significant cross-border differences in either Roman roads or distance to urban centers, or in any of the four pre-Christian land uses. This dismisses the possibility that differences in economic and political power concentration between both sides of the frontier merely reflect a perpetuation of pre-existing differences in land uses or in access to trade routes or commercial centers. $^{25}$

[Insert Table 2 about here]

\subsection{Border Specification}

We next estimate the following border specification:

$$
Y_{i, j}=\alpha_{0}+\phi_{j}+\alpha_{1} \cdot \text { Castilian_Andalusia }_{i}+X_{i}^{\prime} \beta+\varepsilon_{i}
$$

where $Y_{i, j}$ is our dependent variable in municipality $i$ along segment $j$ of the Granada frontier, $\alpha_{0}$ is a constant term, $\phi_{j}$ is a set of four equal-length segments of the frontier (boundary fixed effects) representing the closest one to the municipality centroid, ${ }^{26}$ Castilian_Andalusia $_{i}$ is a dummy variable indicating that the municipality belonged to the Castilian part of Andalusia, $X_{i}$ represents a vector of control variables, and $\varepsilon_{i}$ is the error term. The equation is estimated with ordinary least squares (OLS).

Regarding the vector of control variables, we first include indicators related to suitability for agriculture and land productivity, which affect the size and profitability of landholdings. These

\footnotetext{
${ }^{25}$ As a robustness check, Appendix F provides regression discontinuity (RD) figures plotting the actual values and the local averages of each of these factors in terms of their distance to the frontier along with $90 \%$ confidence intervals. It also contains the regression counterparts to these graphs, which provide point estimates of the jump using a quadratic polynomial in distance to frontier. In essence, the balancedness testing indicates that balance generally holds across both sides of the border (in only one out of the 21 dimensions considered -the percentage of non-intensive agricultural surface- there is evidence of marginally significant differences at the $10 \%$ level).

${ }^{26}$ These segments allow us to compare municipalities across the same segment of the frontier. They can be thought of as capturing geographic treatment effect heterogeneity (Dell, 2010), as the treatment effect may vary along the geographic frontier. For other studies incorporating segment fixed effects in the RD specification, see Dell (2010) and Dell, Lane and Querubín (2015).
} 
indicators are altitude, ruggedness of the terrain, a direct measure of soil quality, annual rainfall, and average temperature. We also include a coast dummy that can proxy for access to external markets in which agricultural products could be sold. The results are reported in Panel A of Table 3 and appear to confirm the evidence from unconditional mean differences in Table $1 .^{27}$

\section{[Insert Table 3 about here]}

\subsection{Spatial Regression Discontinuity Analysis}

Once we have determined the existence of a statistically significant average effect of the Castilian dummy on the concentration of economic and political power through the border specification, we now shift to the application of a semiparametric spatial RDD, as in Dell (2010) and Becker et al. (2015). In the presence of a causal impact of the frontier, there must be a spatial pattern of economic and political power concentration with discontinuous jumps at the frontier. The aim is to identify causal effects by distinguishing between, on the one hand, the treatment effect of the frontier, which is nonlinear and discontinuous in terms of both longitude and latitude, distance to the frontier, and distance to Madrid (depending on the definition of the forcing variable), and on the other, the smooth effects of the climatic and geographic characteristics (see more details in Angrist and Pischke 2009, and Dell 2010). The baseline regression in the RDD takes the form:

$$
Y_{i, j}=\alpha_{0}+\phi_{j}+\alpha_{1} \cdot \text { Castilian__Andalusia }_{i}+X_{i}^{\prime} \beta+f\left(\text { geographic location }_{i}\right)+\varepsilon_{i}
$$

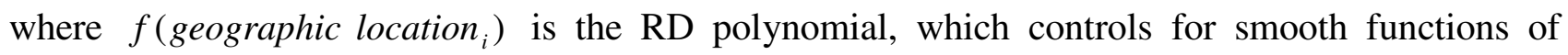
geographic location, and the rest is as described in Equation (1). Before presenting the results from the application of the RDD, we need to determine our baseline specification for the RD polynomial, i.e., the order of the polynomial. In this regard, Gelman and Imbens (2014) have recently shown that linear and quadratic polynomials in the forcing variable perform much better than cubic or higherorder polynomials, which often provide misleading confidence intervals based on such regressions. For completeness purposes, we present the results for the case of several forcing variables: the geographic coordinates, distance to the frontier, distance to Madrid and distance to Seville (the latter appearing in the supplementary appendix). Table 3 presents the estimation of our baseline RD specifications: one of a quadratic multidimensional RD polynomial in latitude and longitude (Panel B), and one of a quadratic single-dimensional polynomial in either distance to the frontier (Panel C)

${ }^{27}$ The results indicate that the fact a municipality is located on the Castilian side of the frontier (and hence affected by the treatment) is associated with a $10.8 \%$ rise in the percentage of landless workers, a rise in mayor hacendado's income over land area of 1025.4 reales $/ \mathrm{km}^{2}$, and a $25.8 \%$ increase in the percentage of municipalities under the jurisdiction of privileged orders. 
or distance to Madrid (Panel D). The basic control set includes the six geographic-climatic controls and the four segment fixed effects. The analysis is conducted with both heteroskedasticity-consistent standard errors and Conley (1999) standard errors robust to spatial correlation of unknown form. ${ }^{28}$

It is worth stressing that the frontier dummy exerts a statistically significant positive effect on the five outcomes in the case of the single-dimensional RD polynomial in distance to the frontier or distance to Madrid. In the case of the more flexible, but also more demanding specification, i.e., the quadratic multidimensional RD polynomial in latitude and longitude, the frontier dummy appears statistically significant at the 5\% level or higher for four outcomes (all but privileged orders jurisdiction). This pattern of results should not come as a surprise, since the higher flexibility associated with the multidimensional RD polynomial comes at the expense of fewer degrees of freedom, which in the case of a relatively small number of observations and measurement errors in the dependent variables may inflate the standard errors and reduce the precision of the estimation (see more details in Dell 2010, and references therein).

For robustness purposes, we next provide a full set of specification tests that includes the use of linear and cubic polynomials in the three forcing variables considered. More specifically, the results from the estimation of a spatial RD specification of linear and cubic polynomials in latitude and longitude (Panels A and D in Table 4), and in distance either to the frontier (Panels B and E) or to Madrid (Panels $\mathrm{C}$ and F), fully corroborate the findings from the spatial RD specification of quadratic form. It is worth noting that when the highly demanding cubic specification in longitude and latitude is used, the results in favor of a statistically significant treatment effect is slightly lower (being significant for three outcomes). However, given the simulation evidence by Gelman and Imbens (2014), we base our conclusions primarily on the linear and quadratic functions of geographic location. In addition, we let the geographic location function differ on both sides of the frontier by including interacted quadratic polynomials in distance to the frontier (assessed at different percentiles of its distribution), distance to Madrid and distance to Seville. As shown in Table A4 in Appendix G, our baseline findings remain fairly robust to allowing polynomials to have different coefficients on both sides of the frontier by interacting the frontier dummy with the respective polynomials.

[Insert Table 4 about here]

\footnotetext{
${ }^{28}$ Thus, we control for spatial correlation through a polynomial in geographic location when using robust standard errors, whereas we double correct for spatial correlation by further using Conley standard errors on top of the RDD.
} 
Figures 5 and 6 are RD plots that provide graphical evidence of the discontinuity in outcomes at the frontier, using the quadratic specification. First, in Figure 5 we follow the standard approach of ordering observations (expressed as local averages of the outcomes) along a one-dimensional line, in our case distance to the frontier. It appears that there is a clear jump at the frontier in the percentage of landless workers, mayor hacendado's income over land area and privileged orders jurisdiction, whereas in the current inequality measures the difference across both sides of the frontier is much less clear. ${ }^{29}$ Second, Figure 6 presents two-dimensional RD plots that are analogous to the ones in Dell (2010). Each plot represents dots with the municipality values for the outcome variables, with each data point being located in the municipality centroid (with its latitude on the $y$ axis and its longitude on the $x$ axis). The background color in each plot represents the predicted values for a onekilometer grid, from a regression on a quadratic polynomial in latitude-longitude and the Castilian dummy, with a darker color indicating a higher predicted value. In support of our hypothesis, we can observe that both real and predicted values are higher on the Castilian side of the frontier. As in Dell (2010), if we compare the shades of the real data points to those of their associated predicted values, we observe that the RDD properly averages the data across space.

[Insert Figures 5 and 6 about here]

\subsection{Additional Robustness Checks}

Next, we examine whether the results are robust to controlling for the distribution of land uses across the Andalusian territory in the period of al-Andalus between the tenth and twelfth centuries. It may well be the case that large estates are more common in those places where extensive agriculture was the historical form of land use, while small holdings are more frequent in areas of previously intensive agriculture. This is also a general check on the importance of initial conditions in the territory, as areas with intensive agriculture in Muslim times were generally more densely populated and wealthier. As shown in Appendix $\mathrm{H}$, the inclusion of the historical form of land use does not overturn our baseline findings.

\footnotetext{
${ }^{29}$ An explanation for this could be that differences -leading to sharp discontinuities just at the border- may have dissipated over time due to spatial integration. Hence, it seems reasonable to assess the existence of an effect a bit further from the frontier. In addition, there are no municipalities whose centroids are just on the border -the closest municipality to the frontier on the Castilian side is $1,300 \mathrm{~m}$ and $75 \%$ of them are at least $7 \mathrm{~km}$ far off the frontier-, which implies that the discontinuity at the border is based on extrapolation. For these reasons, we examine the presence of a frontier effect not only at the frontier, but also at the 25, 50 and 75 percentiles of the distance to the frontier distribution. As shown in Table A4 in Appendix G, the existence of a significant frontier effect at the 25, 50 and 75 percentiles of the distribution of distance to the frontier indicates that the effect of the frontier of Granada on land inequality has persisted over time right through to the present day.
} 
In Section 3, we argued in favor of defining the frontier as it was in 1481, before the beginning of the Granada war and the conquest of Granada itself. We thus ensure that the control group, to which the Castilian part of Andalusia (forming the treatment group) is compared, does not contain municipalities that have ever been treated (i.e., exposed to the frontier treatment at some point in time). Nevertheless, Appendix I checks for the robustness of our baseline results to 1) controlling for those municipalities that were subjected to treatment for a shorter period, i.e., those conquered during the fourteenth and fifteenth century, respectively, 2) including the duration of the frontier treatment, and 3) redefining the frontier circa 1300 and circa 1400. It is remarkable that none of these sensitivity checks alters our baseline findings. Interestingly, the coefficient on the duration variable (which measures whether the duration of the frontier treatment changes the impact on the outcomes) is statistically insignificant. This indicates that what matters is to have ever been part of the Castilian side of Andalusia, rather than the years under the frontier treatment.

Appendix $\mathbf{J}$ provides further robustness checks, such as the use of distance to Seville as an alternative forcing variable and of alternative bandwidths of 40 and 60 kilometers, controlling for municipality size and transportation costs measured through distance to roads in the eighteenth century and distance to the capital city of the respective province, as well as removing the westernmost segment that covers the area near the Gibraltar Strait which exhibited high instability (particularly during the second half of the thirteenth century due to Beni Merin incursions). It is worth noting that they all corroborate our baseline findings.

Another potential concern with the findings presented so far is that rather than capturing a genuine effect of the frontier of Granada, they might only reflect structural differences in the northwestsoutheast dimension. To dismiss this possibility, we apply a falsification test that consists in moving the frontier 50 kilometers northwestward, that is, inland. In this way, we again divide Andalusia into two parts, but this time with a spurious frontier. We then check whether the new "frontier" has any effect on the dependent variables. The results provided in Appendix $\mathrm{K}$ show that this placebo frontier does not generate statistically significant differences between municipalities located on both sides of the frontier. ${ }^{30}$

\footnotetext{
${ }^{30}$ Appendix $\mathrm{K}$ also contains a map with the location of this spurious frontier. In addition, we show that very similar results are obtained when moving the frontier 50 kilometers northward.
} 
To further examine the possibility that our results might simply be due to chance, we conduct a more systematic falsification test consisting in drawing 1,000 random placebo borders. ${ }^{31}$ Then we run our baseline RD specifications with these placebo frontiers and compare the coefficients obtained from this exercise with the "true" coefficients reported in Panels B, C and D of Table 3. As suggested by Abadie, Diamond and Hainmueller (2015), placebo studies constitute an alternative way to analyze the significance of the results. Applied to our case study, the confidence in our findings about the effect of the frontier would be undermined if we frequently find effects of similar or greater magnitudes using placebo borders. Appendix L provides a figure plotting the cumulative distributions of coefficients from this placebo exercise for the specifications with a polynomial in the geographic coordinates, distance to frontier and distance to Madrid. The vertical lines indicate the value of the Castilian dummy in our baseline RD estimations. In all cases but two the "true" effect is higher than the $95 \%$ of the placebo effects. Taking the average of the 15 distributions, the likelihood of obtaining an estimate greater than or equal to the one obtained for the real frontier is lower than 5\%. This makes us confident that our findings are not due to chance, but to the distinct influence that the frontier of Granada has exerted on political and economic inequality in Andalusia.

\subsection{Discussion}

The evidence suggests that the frontier of Granada led to a high concentration of economic and political power on the Castilian side, and that this effect has persisted down to the present day. Another possible interpretation of our findings could be that the Muslim Kingdom of Granada was particularly egalitarian, and that the social structure of this region endured over time, thus failing to converge with the remainder of Andalusia and Castile. However, this interpretation does not match the historical facts and empirical evidence. The social order in the Nasrid Kingdom of Granada was no more equal than in other Muslim kingdoms in al-Andalus prior to their conquest. According to Lévi-Provençal (1932) and Brenan (1950), the greater part of the land in eleventh and twelfthcentury al-Andalus belonged either to the state or to small peasant farmers. State lands normally had the best soil, and were cultivated by serfs who handed over two-thirds of their crop to the state, with private settlers having to deliver an even higher proportion. According to Brenan (1950, p. 127), in

\footnotetext{
${ }^{31}$ More specifically, we draw frontiers between latitudes $37^{\circ} \mathrm{N}$ and $38^{\circ} \mathrm{N}$. For each centesimal fraction of a longitude degree we generate a latitude coordinate following a random walk process. Municipalities are then assigned to the placebo treatment group if their centroids are to the north of the randomly drawn frontier. Given the novelty of this falsification exercise, Appendix L provides the details about how we operationalize it.
} 
al-Andalus "nothing was permitted to infringe upon the powers of the central government." 32 This was indeed the case with the Sultan of the Nasrid Kingdom of Granada, who had absolute power over his subjects. This power was reflected in a complex tax system fully controlled by the state that taxed heavily the Nasrid population (Arié, 1992; Viguera Molins, 1995; Molina-López, 2002). ${ }^{33}$ In order to control tax collection, the Nasrid territory was divided into large jurisdictional areas (that were considered as administrative and fiscal units) in which state agents operated. The local powers controlling these units were not autonomous and depended entirely on the Sultan (Ladero Quesada, 1989). Not surprisingly, the maximum beneficiary of the Nasrid tributary system was the Sultan and his family, whose personal wealth in terms of land, fortresses and palaces was very high (Viguera Molins, 2000; Molina-López, 2002). ${ }^{34}$

Importantly, the Reconquista changed the kind of society and power relations encountered by the Kingdom of Castile upon the conquest of Granada. This was particularly the case after the forced conversion of the Muslim population in 1501, by which the Capitulations of Granada were unilaterally declared to be null. Conversion not only brought about the suppression of the legal, fiscal and religious status of the Muslim population, but also the replacement of their political institutions by the legal-administrative order of the rest of Castile (Pérez Boyero, 2002). The new fiscal system simplified the Nasrid system and was based on the diezmo and alcabala, which were levied mainly on the Morisco population. ${ }^{35}$ In addition, the Catholic Monarchs implemented a policy of fragmenting the former Nasrid jurisdictions, some of which were granted as lordships to nobles. According to Pérez Boyero (2002), this served as an instrument for breaking the sociopolitical organization of the Muslim population, which ensured their control. The Crown articulated the social organization and power relations around major urban centers in which the feudal legaladministrative apparatus prevalent in the rest of Castile was implanted. The main positions in the town councils (regidores and jurados) were elected directly by the Crown among the influential groups, eventually becoming part of the elites' patrimony. The exploitation of the Morisco population and its general rejection by the old Christians resulted in a great revolt and the final expulsion of about 100,000 Moriscos in 1570. With this event, economic equilibrium and fiscal

\footnotetext{
${ }^{32}$ This accords with Blaydes and Chaney (2013), who provide evidence of the high concentration of power in the hands of Muslim sultans during the Middle Ages.

${ }^{33}$ According to Trillo San José (2002), religion was considered the key element of social cohesion and obedience to the central power, whose clear manifestation was the payment of taxes.

${ }^{34}$ According to Arié (1992), vast large estates in the hands of the Sultan were located in the most fertile part of the Granada's plain.

${ }^{35}$ Under the new feudal structure, the surplus would be appropriated by the lordships, whereas in the tributary society of Nasrid Granada it would be appropriated by the state (Trillo San José, 2002).
} 
sufficiency in the former Kingdom of Granada came to a halt (Galán-Sánchez, 2012). The intensive agrarian system based on irrigated arboriculture and horticulture was fully replaced by the Castilian model of extensive agriculture based on cereal crops and cattle (Caro Baroja, 1957).

In sum, all these events show that the Nasrid socioeconomic and political apparatus was fully dismantled at the expense of a feudal structure controlled by the urban oligarchies and landowning nobility, who would progressively become the main social and political players of the newly conquered territory. However, a key difference in this case is that the new territory was not a frontier region (the frontier ceased to exist), and the dynamics affecting a frontier region did not therefore apply to it. Consequently, despite eventually converging to the Castilian feudal socioeconomic and political structure, society did not evolve toward such high levels of inequality, as in the case of the other part of Andalusia. It then becomes apparent that the existence of a frontier played a key role in generating such high levels of political and economic inequality on the Castilian side. In this regard, it is important to note that it was the frontier region of Andalusia that recorded particularly high levels of inequality relative to the rest of Castile, and not that the Kingdom of Granada was particularly egalitarian. The 1787 census indicates that the Castilian part of Andalusia had the highest percentage in Spain of landless workers in terms of overall agricultural population (87.4\%), much higher than the Castilian average (51\%), while the former Kingdom of Granada also had a relatively high percentage $(72 \%)$.

\section{Spatial RDD Using Microdata}

We next complement the above results obtained for measures of land concentration at municipal level with an analysis conducted with microdata from the 1982 agricultural census, which provides us with almost 129,000 observations of agricultural holdings located within 25 kilometers of the frontier. The two variables used are the size of the respective landholding measured by its UAA, and a dummy variable indicating whether the agricultural holding is greater than or equal to 200 hectares in terms of UAA. In both cases, we consider only private agricultural holdings (owned by private individuals or legal entities). In order to compare the two sides of the frontier (using microdata) in a meaningful way, individual observations are weighted by the total size of the holding given by its total surface area. Therefore, in those specifications that use as dependent variable the large estate dummy, the coefficient on the Castilian dummy represents the difference in the percentage of agricultural area belonging to large estates on each side of the border. In other words, it indicates the difference in the probability of being part of a large estate for a randomly selected hectare of land. Note that what matters is not the number of large estates in absolute terms, but the area occupied by 
large estates. ${ }^{36}$ A similar reasoning applies when the dependent variable is a holding's utilized agricultural area. In this case, the coefficient on the Castilian dummy represents the expected difference in landholding size for a randomly selected hectare of land.

Table 5 presents the results for quadratic polynomials in latitude and longitude, as well as in distance to the frontier and to Madrid. Columns 1 and 2 control for boundary fixed effects. Columns 3 and 4 incorporate a set of individual controls that includes the variable "company", indicating whether the holding is managed by a legal entity rather than by a private individual, "the ratio of utilized agricultural area to total surface area" as an indirect measure of land quality -since it represents the percentage of the landholding area that is usable-, "pastureland" reflecting whether the holding has no arable land, and a set of dummies indicating the type of tenure system at micro level. To this set of individual controls, columns 5 and 6 incorporate the set of municipality-level geographic and climatic controls, and columns 7 and 8 also add the measures of pre-Christian land uses in al-Andalus. Standard errors are clustered at municipal level. As shown in Table 5, the coefficients on both utilized agricultural area and the large estate dummy are positive and highly significant across different specifications. Taking the coefficients in Panel B, columns 7 and 8, we find that the Castilian part of Andalusia has landholdings that are 148.4 ha bigger and $11 \%$ more surface area in large estates than the former Kingdom of Granada. This again supports a higher concentration of land on the Castilian side of the frontier.

[Insert Table 5 about here]

\section{The Effect of the Frontier on Contemporary Outcomes}

The general thrust of Acemoglu and Robinson's work is that political and economic inequality is harmful to development. Given the above results regarding the persistent effect that the presence of a stable frontier between Castile and the former Kingdom of Granada had on inequality, this constitutes an opportunity for testing the empirical validity of Acemoglu and Robinson's hypothesis within the context of the frontier of Granada. The line of argument is that the frontier of Granada created a high level of inequality, which persisted over time, thus inhibiting long-term development.

This is operationalized empirically via a two-stage least squares (2SLS) analysis. In a first stage, we try to explain historical inequality on the basis of the frontier dummy as follows:

\footnotetext{
${ }^{36}$ See Appendix M for an example illustrating this, and the results of the RDD without weighting by the total size of the holding, which appear to confirm the existence of a statistically significant frontier effect.
} 


$$
\text { historical_inequality }_{i}=\gamma_{0}+\gamma_{1} \cdot \text { Castilian_Andalusia }_{i}+X_{i}^{\prime} \beta+\varepsilon_{i}
$$

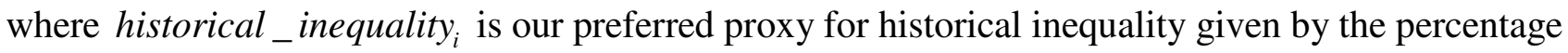
of landless workers in the eighteenth century, ${ }^{37}$ Castilian_Andalusia $_{i}$ and $X_{i}$ are as described in Equation 1. In a second stage, several current development outcomes are regressed on the predicted value of historical inequality and the set of exogenous controls, such that:

$$
\text { current_outcomes }_{i}=\delta_{0}+\delta_{1} \cdot \text { historical_inequality }{ }_{i}+X_{i}^{\prime} \varphi+v_{i}
$$

where current_outcomes r $_{i}$ represent several contemporary outcomes linked to economic development such as a municipality's average socieconomic condition, the ratio of cars to population, the education level of the population between 30 and 39 years, the percentage of labor force employed in industry and services, and long-term population growth over the 1950-2010 period. In addition, we employ two measures of current political power concentration: the number of changes in the political party at the local government level affecting the election of the mayor, and the number of political parties that have controlled the town council since 1979 (with a higher value implying greater political competition and alternation). We also use the level of local public debt with financial entities per capita in 2008, with a lower value indicating a more responsible fiscal management and in turn higher institutional quality. Finally, we use the number of immigrants per 1,000 inhabitants. According to the theoretical setting of regional development in Gennaioli et al. (2013, 2014), more dynamic and prosperous regions tend to receive more immigrants and only the most skilled workers choose to migrate. ${ }^{38}$

At this point, it is important to mention that the purpose of this analysis is only to determine whether historically rooted inequality has had an adverse effect on current development outcomes. However, it is not our intention to show that the frontier of Granada is uncorrelated with any determinants of current development, other than historical inequality. In other words, we acknowledge that the exclusion restriction that, -conditional on the exogenous control set- the frontier of Granada affects current development only through its impact on political and economic inequality, is likely to be violated. In statistical terms, $\operatorname{corr}\left(\right.$ Castilian_Andalusia $\left._{i}, v_{i}\right) \neq 0$. Therefore, the evidence in this section can be thought of as correlational, but not causal. Indeed, there could be other channels

\footnotetext{
${ }^{37}$ Note that similar results follow when we measure the extent of inequality through the percentage of UAA in holdings with 200 hectares or more in 1982. The results appear in Table A20 in Appendix N. We prefer to leave in the main text the results obtained with historical inequality, since the exclusion restriction is likely to be violated to a greater extent for current measures of inequality.

${ }^{38}$ For our municipalities sample, there is indeed a highly statistically significant and positive correlation between the immigration rate and the other outcome variables related to development.
} 
through which the existence of the frontier may have affected current outcomes. They include the level of trust and social capital that could result from living in frontier areas usually subjected to war and incursions. Frontier warfare could also affect the preservation of agricultural technologies and irrigation infrastructure, and it is possible that on the Castilian side they were more severely destroyed. Since there are no historical data at municipal level to account for all these potential channels, we focus on the inequality channel, but bearing in mind that the frontier of Granada is likely to affect contemporary development outcomes also through other channels.

The 2SLS analysis, reported in Table 6 for the nine contemporary development outcomes considered, provides clear-cut evidence that in the first stage the frontier treatment increases historical inequality on the Castilian side, as measured by the percentage of landless workers in 1787. In the second stage, the part of historical inequality that is due to the frontier has a highly significant negative effect on contemporary economic development (as measured by average socioeconomic condition, cars per capita, education level of the population between 30 and 39 years, percentage of employment in industry and services, long-term population growth and the immigration rate) and on our measures of political competition, as well as a positive effect on local public debt per capita, which indicates lower institutional quality. It is worth noting that the first stage appears strong across the different specifications of the polynomials in geographic location, ${ }^{39}$ whereas the second stage's key coefficient appears highly significant for the specifications with no polynomial and those with single-dimensional polynomials in distance either to the frontier or to Madrid.

To have an idea of the magnitudes of the effect, the bottom row of Table 6 provides the average value of each outcome variable. For instance, column 4 of Panel $\mathrm{C}$ indicates that a $1 \%$ rise in the part of the percentage of landless workers that is due to the frontier is associated with a $0.65 \%$ decline in the share of employment in industry and services. In addition, column 9 indicates that a $1 \%$ increase in the part of historical inequality that is due to the frontier is associated with a $0.84 \%$ fall in the average immigration rate over the 1988-2014 period. Economically relevant effects are also found for the other contemporary outcomes. ${ }^{40}$ Thus, we can conclude that there is evidence

\footnotetext{
39 The first-stage F-statistic generally exceeds the "rule-of-thumb" value of 10 (Staiger and Stock, 1997), which in a pure instrumental variables framework would indicate the absence of a weak-instrument problem.

${ }^{40}$ Table A21 in Appendix N contains the results from a 2SLS exercise in which the frontier dummy is used to predict historical inequality in the first stage, and then current inequality measures are regressed on the predicted value of historical inequality, in both stages controlling for the baseline control set. As expected, there is correlational evidence to support the existence of an adverse effect of the frontier on historical inequality, which has persisted over time right through to the twentieth century. Appendix N also contains Table A22 that presents the estimates of the reduced-form
} 
favoring the empirical validity of Acemoglu and Robinson's hypothesis that structural inequality caused by arguably exogenous events (in our case the presence of a frontier) inhibits long-term development.

[Insert Table 6 about here]

\section{Conclusions}

This paper has explored the political economy that leads frontier regions to be unequal. We establish the hypothesis that, in the presence of a military threat, frontiers must be defended and this fact biases the political equilibrium in favor of the military elite, which ends up accumulating an enormous amount of economic and political power. We empirically test this hypothesis by exploiting the existence of a frontier between Castile and the Nasrid Kingdom of Granada in the late Middle Ages. Through the application of a border specification and a spatial RDD, we find that municipalities on the Castilian side have a significantly higher percentage of landless workers, a greater accumulation of wealth, and more jurisdictional rights among the privileged orders, as measured in the eighteenth century. These findings support the argument that the dynamics of being an insecure frontier region created the conditions on the Castilian side for a high concentration of power. We use current indicators of land inequality and development to show that the effect of the frontier of Granada persists even today.

These results are robust to controlling for a large number of observable characteristics, employing a border specification or a semiparametric spatial RDD, and using microdata for a sample of almost 129,000 holdings. The results are also robust to a series of falsification tests checking for differences in climatic, geographic, and pre-existing conditions across the two sides of the frontier as well as to a series of falsification tests consisting in either drawing 1,000 random placebo borders or moving the true frontier northwestward and northward.

The hypothesis introduced in this paper is consistent with the "conditional frontier thesis" proposed by García-Jimeno and Robinson (2011), since the negative consequences of the frontier were due to a political equilibrium characterized by a high concentration of political power in the hands of the privileged orders (particularly the nobility). As documented above, the fact it was an insecure frontier region led to a balance of power that clearly favored the nobles' interests. The consequences of the frontier decisively affected the repopulation and social organization of the Castilian part of Andalusia and, in this way, the future of this Spanish region. In conclusion, this article has

effect of the frontier of Granada on contemporary development outcomes. Again, the evidence indicates that the existence of the frontier exerts a statistically significant negative effect on current outcomes. 
contributed to the still very scarce and novel literature on the political-economic effects of historical frontiers. It has also contributed to the vibrant literature that seeks to explain the development paths of societies on the basis of historical events occurring in the distant past, as well as to answer the question of why Andalusia has suffered such a high level of inequality throughout its modern history.

\section{References}

Abadie, Alberto, Alexis Diamond, and Jens Hainmueller (2015). "Comparative Politics and the Synthetic Control Method.” American Journal of Political Science, 59 (2), 495-510.

Acemoglu, Daron, Maria Angelica Bautista, Pablo Querubin, and James A. Robinson (2008). "Economic and Political Inequality in Development: The Case of Cundinamarca, Colombia." In Institutions and Economic Performance, edited by Elhanan Helpman, Harvard University Press, Cambridge, MA.

Acemoglu, Daron, Simon Johnson, and James A. Robinson (2001). "The Colonial Origins of Comparative Development: An Empirical Investigation.” American Economic Review, 91 (5), 1369-401.

Acemoglu, Daron, and James A. Robinson. (2006). "De Facto Political Power and Institutional Persistence.” American Economic Review, 96 (2), 325-330.

Acemoglu, Daron, and James A. Robinson. (2010). "The Role of Institutions in Growth and Development." Review of Economics and Institutions, 1 (2), 1-33.

Acemoglu, Daron, and James A. Robinson. (2012). Why Nations Fail. Crown Publishers, New York.

Acemoglu, Daron, and Alexander Wolitzky. (2011). "The Economics of Labor Coercion." Econometrica, 79(2), 555-600.

Angrist, Joshua D., and Jörn-Steffen Pischke (2009). Mostly Harmless Econometrics: An Empiricist's Companion. Princeton University Press, Princeton.

Arié, Rachel. 1992. El Reino Nasrí de Granada (1232-1492). Editorial MAPFRE S.A., Madrid.

Artola, Miguel, Antonio M. Bernal and Jaime Contreras (1978). El Latifundio. Propiedad y Explotación ss. XVIII-XX. Servicio de Publicaciones Agrarias, Madrid.

Bai, Ying, and James Kai-sing Kung (2011). "Climate Shocks and Sino-nomadic Conflict." Review of Economics and Statistics, 93 (3), 970-981.

Bai, Ying, and James Kai-sing Kung (2015). "Diffusing Knowledge while Spreading God's Message: Protestantism and Economic Prosperity in China, 1840-1920." Journal of European Economic Association, 13 (4), 669-698. 
Banerjee, Abhijit, and Lakshmi Iyer (2005). "History, Institutions, and Economic Performance: The Legacy of Colonial Land Tenure Systems in India." American Economic Review, 95, 11901213.

Becker, Sascha O., Katrin Boeckh, Christa Hainz and Ludger Woessmann (2015). "The Empire Is Dead, Long Live the Empire! Long-Run Persistence of Trust and Corruption in the Bureaucracy." Economic Journal, forthcoming.

Becker, Sascha O., and Ludger Woessmann (2009). "Was Weber Wrong? A Human Capital Theory of Protestant Economic History.” Quarterly Journal of Economics, 124 (2), 531-596.

Blaydes Lisa, and Eric Chaney (2013). "The Feudal Revolution and Europe's Rise: Political Divergence of the Christian West and the Muslim World before 1500 CE." American Political Science Review, 107(1), 16-34.

Brenan, Geral (1950). The Spanish Labyrinth: An Account of the Social and Political Background of the Spanish Civil War. Cambridge University Press, Cambridge.

Brenner, Robert (1976). "Agrarian Class Structure and Economic Development in Pre-Industrial Europe." Past and Present, 70, 30-75.

Brenner, Robert (1982). "The Agrarian Roots of European Capitalism”, Past and Present, 97, 16113.

Bruhn, Miriam, and Francisco A. Gallego (2012). "Good, Bad, and Ugly Colonial Activities: Do They Matter for Economic Development?" Review of Economics and Statistics, 94 (2), 433 461.

Burns, Robert I. (1976). Medieval Colonialism: Postcrusade Exploitation of Islamic Valencia. Princeton University Press, Princeton.

Cabrera Muñoz, Emilio (1989). "The Medieval Origins of the Great Landed Estates of the Guadalquivir Valley." Economic History Review, 42 (4), 465-483.

Cabrera Muñoz, Emilio (2006). "Feudalismo y Señoríos en Andalucía (Siglos XIII al XV)." In Historia de Andalucía IV: El Nacimiento de Andalucía, edited by Manuel González Jiménez, Planeta Editorial, Barcelona, pp. 106-134.

Cantoni, Davide (2015). "The Economic Effects of the Protestant Reformation: Testing the Weber Hypothesis in the German Lands." Journal of the European Economic Association, 13 (4), 561-598.

Caro Baroja, Julio (1957). Los Moriscos del Reino de Granada. Institutos de Estudios Políticos, Madrid.

Caro Baroja, Julio (1966). "La Despoblación de los Campos.” Revista de Occidente, 40, 19-36.

Carrión, Pascual (1975). Los Latifundios en España. Su importancia, Origen. Consecuencias y Solución. Ariel, Barcelona. 
Chaney Eric (2013) "Revolt on the Nile: Economic Shocks, Religion and Political Power." Econometrica, 81(5), 2033-2053.

Chaney, Eric, and Richard Hornbeck (2015). "Economic Dynamics in the Malthusian Era: Evidence from the 1609 Spanish Expulsion of the Moriscos". Economic Journal, forthcoming.

Conley, Timothy (1999). "GMM Estimation with Cross Sectional Dependence." Journal of Econometrics, 92, 1-45.

Dell, Melissa (2010). “The Persistent Effects of Peru's Mining Mita.” Econometrica, 78 (6), 18631903.

Dell, Melissa, Nathan Lane, and Pablo Querubín (2015). "State Capacity, Local Governance, and Economic Development in Vietnam.” Harvard University Working Paper.

Dewald, Jonathan (2004). Europe 1450 to 1789: Encyclopedia of the Early Modern World. Charles Scribner's Sons, New York.

Engerman, Stanley L., and Kenneth L. Sokoloff (1997). "Factor Endowments, Institutions, and Differential Paths of Growth among New World Economies." In How Latin America Fell Behind, edited by Stephen Haber, Stanford University Press, Stanford, CA, pp. 260-304.

Fenske, James (2012). "Land Abundance and Economic Institutions: Egba Land and Slavery, 18301914." The Economic History Review, 65 (2), 527-555.

Fenske, James (2013). "Does Land Abundance Explain African Institutions?" Economic Journal, 123 (573), 1363-1390.

Fenske, James (2014). "Ecology, Trade and States in Precolonial Africa." Journal of European Economic Association, 12 (3), 612-640.

Forey, Alan J. (1984). "The Military Orders and the Spanish Reconquest in the Twelfth and Thirteenth Centuries.” Traditio, 40, 197-234.

Galán Sánchez, Ángel (2012). "Poder y Fiscalidad en el Reino de Granada Tras la Conquista: Algunas Reflexiones." Studia historica. Historia Medieval. 30, 67-98.

Gallego, Francisco A. (2010). "Historical origins of schooling: The role of democracy and political decentralization." Review of Economics and Statistics, 92 (2), 228-243.

García-Jimeno, Camilo, and James A. Robinson (2011). "The Myth of the Frontier." In Understanding Long-Run Economic Growth, edited by Dora L. Costa and Naomi R. Lamoreaux, University of Chicago Press, Chicago, pp. 49-88.

Gelman, Andrew, and Imbens, Guido. (2014). "Why High-order Polynomials Should Not Be Used in Regression Discontinuity Designs." NBER Working Paper 20405. National Bureau of Economic Research, Cambridge, Massachusetts.

Gennaioli, Nicola, and Ilia Rainer. (2007). "The Modern Impact of Precolonial Centralization in Africa." Journal of Economic Growth, 12 (3), 185-234. 
Gennaioli, Nicola, Rafael La Porta, Florencio López de Silanes, and Andrei Shleifer. (2013). "Human Capital and Regional Development." Quarterly Journal of Economics, 128 (1), 105164.

Gennaioli, Nicola, Rafael La Porta, Florencio López de Silanes, and Andrei Shleifer. (2014). "Growth in Regions." Journal of Economic Growth, 19, 259-309.

Gerhard, Dietrich (1959). "The Frontier in Comparative View." Comparative Studies in Society and History, 1 (3), 205-229.

González Jiménez, Manuel (1981a). “La Repoblación de Andalucía en el Siglo XIII”, In Historia de Andalucía II. La Andalucía Dividida (1013-1350): Orígenes de la Andalucía Cristiana, edited by José Enrique López de Castañer and Manuel González Jiménez, Editorial Planeta, Barcelona, Chapter 2, pp. 129-150.

González Jiménez, Manuel (1981b). “La Repoblación en el Siglo XIV”, In Historia de Andalucía II. La Andalucía Dividida (1013-1350): Orígenes de la Andalucía Cristiana, edited by José Enrique López de Castañer and Manuel González Jiménez, Editorial Planeta, Barcelona. Chapter 4, 183-200.

González Jiménez, Manuel (1989). "Frontier and Settlement in the Kingdom of Castile (10851350)." In Medieval Frontier Societies, edited by Robert Bartlett and Angus MacKay, Clarendon Press, Oxford, pp. 49-74.

González Jiménez, Manuel (2006). "La Conquista y Formación de Andalucía." In Historia de Andalucía IV: El Nacimiento de Andalucía, edited by Manuel González Jiménez, Chapter 1.1, Ediciones Planeta, Barcelona, pp. 12-47.

Grosjean, Pauline (2011a). "The Institutional Legacy of the Ottoman Empire: Islamic Rule and Financial Development in South Eastern Europe." Journal of Comparative Economics, 39(1), $1-16$.

Grosjean, Pauline (2011b). "The Weight of History on European Cultural Integration: A Gravity Approach." American Economic Review, 101(3), 504-508.

Hennessy, C. Alistair M. (1978). The Frontier in Latin American History. Edward Arnold, London.

Iyer, Lakshmi (2010). "Direct versus Indirect Colonial Rule in India: Long-term Consequences." Review of Economics and Statistics, 92 (4), 693-713.

Jovellanos, Gaspar M. de (1795). Escritos Económicos -Gaspar Melchor de Jovellanos. Informe sobre la Ley Agraria. Real Academia de Ciencias Morales y Políticas, Madrid, D.L. 2000.

Ladero Quesada, M. Ángel (1989). Granada, Historia de un País Islámico (1232-1571), Editorial Gredos, Madrid.

Le Roy Ladurie, Emmanuel (1977). The Peasants of Languedoc. University of Illinois Press.

Lévi-Provençal, Evariste (1932). L'Espagne Musulmane au Xiéme Siécle. Institutions et Vie Sociale, Paris. 
Malefakis, Edward (1970). Agrarian Reform and Peasant Revolution in Spain. Origins of the Civil War. Yale University Press, New Haven.

Mestre-Campi, Jesús, and Flocel Sabaté (1998). Atlas de la Reconquista. La Frontera Peninsular entre los Siglos VIII y XV. Ediciones Península, Barcelona.

Molina López, Emilio (2002). "El Reino Nazarí: La Dinámica Política y Los Fundamentos del Poder." In Historia del Reino de Granada, Tomo I: De los Orígenes a la Época Mudéjar (hasta 1502), edited by Rafael G. Peinado Santaella. Editorial Universidad de Granada, Granada, pp. 211-248.

Nadal, Jordi (1975). El Fracaso de la Revolución Industrial en España, 1814-1913. Ariel, Barcelona.

Nadal, J., Carreras, A., and Sudriá, C. (1987). La Economía Española del Siglo XX. Una Perspectiva Histórica. Barcelona, Ariel.

Olavide, Pablo de (1768). "Informe sobre la Ley Agraria." In La Reforma Agraria en Andalucía: el Primer Proyecto Legislativo, edited by Antonio Merchán, Universidad de Sevilla, Sevilla. 1996.

Ortega López, Margarita (1986). La Lucha por la Tierra en la Corona de Castilla al Final del Antiguo Régimen. El Expediente de Ley Agraria. Centro de Publicaciones de la Secretaría General Técnica del Ministerio de Agricultura, Pesca y Alimentación, Madrid.

Oto-Peralías, Daniel, Diego Romero-Ávila (2014a). "The Distribution of Legal Traditions around the World: A Contribution to the Legal Origins Theory." Journal of Law and Economics, 57 (3), 561-628.

Oto-Peralías, Daniel, Diego Romero-Ávila (2014b). "The Economic Consequences of the Spanish Reconquest: The Long-term Effects of Medieval Conquest and Colonization”. Working Paper, Pablo de Olavide University.

Pérez Boyero, Enrique (2002). “La Época Mudéjar: Los Señoríos y el Mundo Rural.” In Historia del Reino de Granada, Tomo I: De los Orígenes a la Época Mudéjar (hasta 1502), edited by Rafael G. Peinado Santaella. Editorial Universidad de Granada, Granada, pp. 567-610.

Postan, Michael M. (1973). "Economic Relations between Eastern and Western Europe." In Medieval Trade and Finance, edited by Michael M. Postan. Cambridge University Press, Cambridge, pp. 305-334.

Rodríguez Molina, José (2000). "Convivencia de Musulmanes y Cristianos en la Frontera de Granada." In La Paz en la Historia, Instituto de la Paz y los Conflictos, Granada, pp. 203-205.

Ruiz-Maya, Luis (1979). "Sobre el Origen Histórico de la Concentración de la Tierra: una Aproximación Estadística.” Agricultura y Sociedad, 10, 9-103.

Staiger, Douglas, and James H. Stock (1997). "Instrumental Variables Regression with Weak Instruments." Econometrica, 65, 557-86. 
Trillo San José, Carmen. (2002). "El Reino Nazarí: Las Actividades Económicas y las Estructuras Sociales." In Historia del Reino de Granada, Tomo I: De los Orígenes a la Época Mudéjar (hasta 1502), edited by Rafael G. Peinado Santaella. Editorial Universidad de Granada, Granada, pp. 292-347.

Truxillo, Charles A. (2001). By the Sword and the Cross: The Historical Evolution of the Catholic World Monarchy in Spain and the New World, 1492-1825. Greenwood Press, London.

Turner, Frederick Jackson (1920). The Frontier in American History. H. Holt and Co., New York.

Tusell, Javier (1976). Oligarquía y Caciquismo en Andalucía (1890-1923). Planeta, Barcelona.

Vicens Vives, Jaime (1969). An Economic History of Spain. Princeton University Press, Princeton.

Viguera Molins, M. Jesús. (1995). De las Taifas al Reino de Granada: Al-Andalus, Siglos XI-XV. Temas de Hoy, Madrid.

Viguera Molins, M. Jesús (2000). "El Soberano, Visires y Secretarios." In El Reino Nazarí de Granada (1232-1492). Vol. 3: Política. Instituciones. Espacio y Economía, edited by José M. Jover Zamora. Espasa, Madrid, pp. 320-355. 
TABLES AND FIGURES

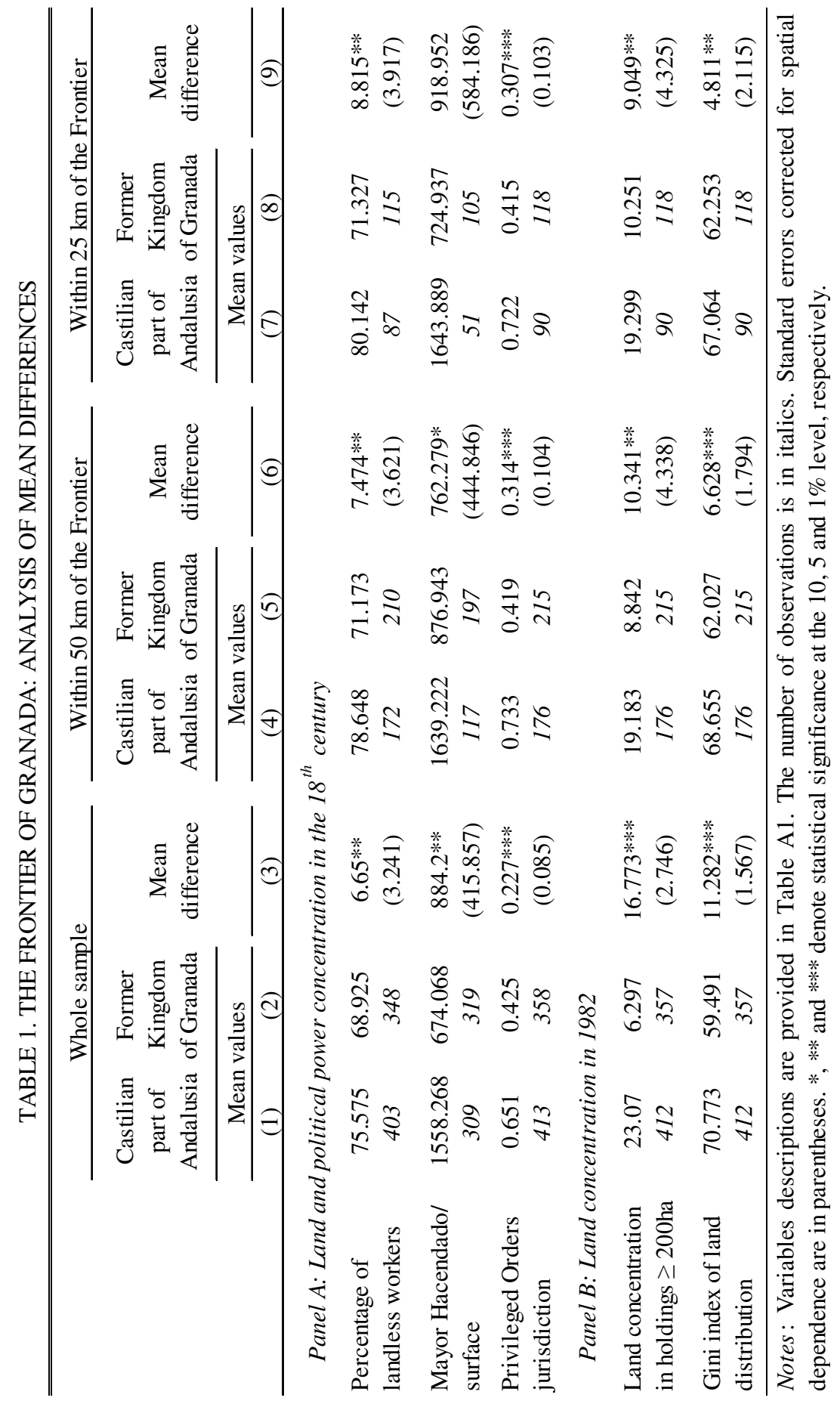


TABLE 2. GEOGRAPHIC, CLIMATIC AND PREEXISTING DIFFERENCES ON BOTH SIDES OF THE FRONTIER

\begin{tabular}{|c|c|c|c|}
\hline & $\begin{array}{l}\text { Castilian part of } \\
\text { Andalusia }\end{array}$ & $\begin{array}{c}\text { Former Kingdom of } \\
\text { Granada }\end{array}$ & \multirow[t]{2}{*}{ Mean difference } \\
\hline & \multicolumn{2}{|c|}{ Mean values } & \\
\hline \multicolumn{4}{|l|}{ Panel A: Differences in geography and climate } \\
\hline Altitude & 622.65 & 690.47 & $\begin{array}{l}-67.819 \\
(92.691)\end{array}$ \\
\hline Ruggedness & 152.95 & 146.78 & $\begin{array}{c}6.169 \\
(40.769)\end{array}$ \\
\hline Surface area with a steep slope (\%) & 43.35 & 49.80 & $\begin{array}{l}-6.445 \\
(12.835)\end{array}$ \\
\hline Coast dummy & 0.03 & 0.04 & $\begin{array}{l}-0.009 \\
(0.027)\end{array}$ \\
\hline Rainfall & 783.81 & 780.28 & $\begin{array}{c}3.533 \\
(112.022)\end{array}$ \\
\hline Temperature & 14.84 & 14.41 & $\begin{array}{c}0.433 \\
(0.399)\end{array}$ \\
\hline Aridity & 0.53 & 0.52 & $\begin{array}{c}0.017 \\
(0.039)\end{array}$ \\
\hline Mediterranean phytoclimate $(\%)$ & 96.19 & 98.09 & $\begin{array}{l}-1.895 \\
(2.714)\end{array}$ \\
\hline \multicolumn{4}{|l|}{ Panel B: Differences in soil quality } \\
\hline Soil quality & 1.78 & 1.65 & $\begin{array}{c}0.131 \\
(0.229)\end{array}$ \\
\hline Moderate or high erodibility ( $\%$ surface area) & 76.30 & 80.95 & $\begin{array}{l}-4.650 \\
(6.981)\end{array}$ \\
\hline Low topsoil carbon (\% surface area) & 81.45 & 86.66 & $\begin{array}{l}-5.211 \\
(7.744)\end{array}$ \\
\hline Fine soil texture ( $\%$ surface area) & 49.04 & 46.60 & $\begin{array}{c}2.440 \\
(8.837)\end{array}$ \\
\hline Arable land ( $\%$ surface area) & 55.90 & 54.33 & $\begin{array}{c}1.565 \\
(10.162)\end{array}$ \\
\hline Crops (\% surface area) & 23.63 & 28.07 & $\begin{array}{c}-4.435 \\
(11.171)\end{array}$ \\
\hline \multicolumn{4}{|l|}{ Panel C: Differences in preexisting conditions } \\
\hline Presence of Roman roads & 0.34 & 0.25 & $\begin{array}{c}0.099 \\
(0.078)\end{array}$ \\
\hline Distance to urban centers in 1200 & 51.21 & 46.02 & $\begin{array}{c}5.196 \\
(6.959)\end{array}$ \\
\hline Distance to urban centers in 1400 & 41.65 & 39.87 & $\begin{array}{c}1.779 \\
(6.361)\end{array}$ \\
\hline $\begin{array}{l}\text { Forest ( } \% \text { surface area, in the } 10^{\text {th }}-12^{\text {th }} \\
\text { centuries) }\end{array}$ & 7.33 & 4.51 & $\begin{array}{c}2.818 \\
(4.509)\end{array}$ \\
\hline $\begin{array}{l}\text { Pastureland ( } \% \text { surface area, in the } 10^{\text {th }}-12^{\text {th }} \\
\text { centuries) }\end{array}$ & 22.92 & 18.84 & $\begin{array}{c}4.087 \\
(4.845)\end{array}$ \\
\hline $\begin{array}{l}\text { Intensive agriculture and irrigation (\% surface } \\
\text { area, in the } 10^{\text {th }}-12^{\text {th }} \text { centuries) }\end{array}$ & 1.66 & 4.13 & $\begin{array}{l}-2.466 \\
(1.598)\end{array}$ \\
\hline $\begin{array}{l}\text { Non-intensive agriculture ( } \% \text { surface area, in } \\
\text { the } 10^{\text {th }}-12^{\text {th }} \text { centuries) }\end{array}$ & 16.69 & 20.78 & $\begin{array}{l}-4.083 \\
(3.493)\end{array}$ \\
\hline Number of observations & 90 & 118 & 208 \\
\hline
\end{tabular}

Notes: Variables descriptions are provided in Table A1. Sample restricted to municipalities within $25 \mathrm{~km}$ of the frontier. Standard errors corrected for spatial dependence are in parentheses. *, ** and *** denote statistical significance at the 10 , 5 and $1 \%$ level, respectively. 
TABLE 3. THE EFFECT OF THE FRONTIER OF GRANADA ON INEQUALITY: SPATIAL RDD

\begin{tabular}{|c|c|c|c|c|c|}
\hline \multirow{3}{*}{ Dependent variable } & \multicolumn{3}{|c|}{$\begin{array}{l}\text { Land and political power concentration in } \\
\text { the } 18^{\text {th }} \text { century }\end{array}$} & \multicolumn{2}{|c|}{ Land concentration in 1982} \\
\hline & $\begin{array}{c}\text { Percentage of } \\
\text { landless } \\
\text { workers }\end{array}$ & $\begin{array}{c}\text { Mayor } \\
\text { Hacendado/ } \\
\text { surface }\end{array}$ & $\begin{array}{l}\text { Privileged } \\
\text { Orders } \\
\text { jurisdiction }\end{array}$ & $\begin{array}{c}\text { Land } \\
\text { concentration in } \\
\text { holdings } \geq 200 \mathrm{ha}\end{array}$ & $\begin{array}{l}\text { Gini index of } \\
\text { land } \\
\text { distribution }\end{array}$ \\
\hline & $(1)$ & $(2)$ & (3) & (4) & $(5)$ \\
\hline \multicolumn{6}{|c|}{ Panel A: OLS-Border specification } \\
\hline Castilian part of Andalusia & $\begin{array}{c}10.788 \\
(2.888)^{* * *} \\
{[2.744]^{* * *}}\end{array}$ & $\begin{array}{c}1025.383 \\
(312.572)^{* * *} \\
{[325.022]^{* * *}}\end{array}$ & $\begin{array}{c}0.258 \\
(0.071)^{* * *} \\
{[0.106]^{* *}}\end{array}$ & $\begin{array}{c}9.707 \\
(2.61)^{* * * *} \\
{[2.376]^{* * * *}}\end{array}$ & $\begin{array}{c}4.598 \\
(1.533)^{* * *} \\
{[1.06]^{* * *}}\end{array}$ \\
\hline$R^{2}$ & 0.26 & 0.37 & 0.22 & 0.29 & 0.21 \\
\hline \multicolumn{6}{|c|}{ Panel B: Quadratic polynomial in latitude and longitude } \\
\hline Castilian part of Andalusia & $\begin{array}{c}9.552 \\
(3.36)^{* * *} \\
{[3.578]^{* * *}}\end{array}$ & $\begin{array}{c}1035.264 \\
(389.623)^{* * * *} \\
{[250.194]^{* * *}}\end{array}$ & $\begin{array}{c}0.061 \\
(0.11) \\
{[0.159]}\end{array}$ & $\begin{array}{c}12.149 \\
(4.311)^{* * *} \\
{[3.751]^{* * *}}\end{array}$ & $\begin{array}{c}4.719 \\
(2.185)^{* *} \\
{[1.974]^{* *}}\end{array}$ \\
\hline$R^{2}$ & 0.31 & 0.42 & 0.29 & 0.35 & 0.25 \\
\hline \multicolumn{6}{|c|}{ Panel C: Quadratic polynomial in distance to the Frontier } \\
\hline Castilian part of Andalusia & $\begin{array}{c}10.523 \\
(2.838)^{* * *} \\
{[2.529]^{* * *}}\end{array}$ & $\begin{array}{c}1104.757 \\
(320.537)^{* * *} \\
{[345.112]^{* * * *}}\end{array}$ & $\begin{array}{c}0.245 \\
(0.07)^{* * *} \\
{[0.103]^{* *}}\end{array}$ & $\begin{array}{c}9.463 \\
(2.666)^{* * *} \\
{[2.372]^{* * *}}\end{array}$ & $\begin{array}{c}4.348 \\
(1.518)^{* * *} \\
{[0.986]^{* * *}}\end{array}$ \\
\hline$R^{2}$ & 0.26 & 0.38 & 0.24 & 0.29 & 0.22 \\
\hline \multicolumn{6}{|c|}{ Panel D: Quadratic polynomial in distance to Madrid } \\
\hline Castilian part of Andalusia & $\begin{array}{c}15.119 \\
(3.134)^{* * *} \\
{[2.607]^{* * *}}\end{array}$ & $\begin{array}{c}1381.763 \\
(353.718)^{* * *} \\
{[316.83]^{* * *}}\end{array}$ & $\begin{array}{c}0.215 \\
(0.086)^{* *} \\
{[0.16]}\end{array}$ & $\begin{array}{c}11.910 \\
(3.182)^{* * *} \\
{[2.652]^{* * *}}\end{array}$ & $\begin{array}{c}5.121 \\
(1.819)^{* * *} \\
{[1.149]^{* * *}}\end{array}$ \\
\hline$R^{2}$ & 0.29 & 0.39 & 0.23 & 0.31 & 0.22 \\
\hline Boundary fixed effects & Yes & Yes & Yes & Yes & Yes \\
\hline Geog.-climatic controls & Yes & Yes & Yes & Yes & Yes \\
\hline Number of observations & 202 & 156 & 208 & 208 & 208 \\
\hline
\end{tabular}

Notes: Variables descriptions are provided in Table A1. Sample restricted to municipalities within $25 \mathrm{~km}$ of the frontier. The set of geographic-climatic controls includes altitude, ruggedness, soil quality, rainfall, temperature and a coast dummy. Robust standard errors are in parentheses, and standard errors corrected for spatial dependence are in brackets. *, ** and $* * *$ denote statistical significance at the 10,5 and $1 \%$ level, respectively. 


\begin{tabular}{|c|c|c|c|c|c|}
\hline \multirow[b]{2}{*}{ Dependent variable } & \multicolumn{3}{|c|}{$\begin{array}{l}\text { Land and political power concentration in } \\
\text { the } 18^{\text {th }} \text { century }\end{array}$} & \multicolumn{2}{|c|}{ Land concentration in 1982} \\
\hline & $\begin{array}{c}\begin{array}{c}\text { Percentage of } \\
\text { landless } \\
\text { workers }\end{array} \\
(1) \\
\end{array}$ & $\begin{array}{c}\begin{array}{c}\text { Mayor } \\
\text { Hacendado/ } \\
\text { surface }\end{array} \\
(2) \\
\end{array}$ & $\begin{array}{l}\begin{array}{c}\text { Privileged } \\
\text { Orders } \\
\text { jurisdiction }\end{array} \\
(3) \\
\end{array}$ & $\begin{array}{c}\text { Land } \\
\text { concentration in } \\
\text { holdings } \geq 200 \mathrm{ha}\end{array}$ & $\begin{array}{c}\begin{array}{c}\text { Gini index of } \\
\text { land } \\
\text { distribution }\end{array} \\
(5)\end{array}$ \\
\hline \multicolumn{6}{|c|}{ Panel A: Linear polynomial in latitude and longitude } \\
\hline Castilian part of Andalusia & $\begin{array}{c}9.148 \\
(3.171)^{* * * *} \\
{[3.455]^{* * *}}\end{array}$ & $\begin{array}{c}1162.491 \\
(497.23)^{* * *} \\
{[337.728]^{* * *}}\end{array}$ & $\begin{array}{c}0.031 \\
(0.1) \\
{[0.137]}\end{array}$ & $\begin{array}{c}12.098 \\
(4.556)^{* * *} \\
{[4.926]^{* *}}\end{array}$ & $\begin{array}{c}3.394 \\
(2.003)^{*} \\
{[1.838]^{*}}\end{array}$ \\
\hline \multicolumn{6}{|c|}{ Panel B: Linear polynomial in distance to the Frontier } \\
\hline Castilian part of Andalusia & $\begin{array}{c}10.540 \\
(2.833)^{* * *} \\
{[2.519]^{* * *}}\end{array}$ & $\begin{array}{c}1102.671 \\
(321.643)^{* * *} \\
{[347.081]^{* * *}}\end{array}$ & $\begin{array}{c}0.245 \\
(0.071)^{* * *} \\
{[0.102]^{* *}}\end{array}$ & $\begin{array}{c}9.461 \\
(2.661)^{* * *} \\
{[2.397]^{* * *}}\end{array}$ & $\begin{array}{c}4.348 \\
(1.511)^{* * *} \\
{[0.973]^{* * *}}\end{array}$ \\
\hline$R^{2}$ & 0.26 & 0.38 & 0.23 & 0.29 & 0.22 \\
\hline \multicolumn{6}{|c|}{ Panel C: Linear polynomial in distance to Madrid } \\
\hline Castilian part of Andalusia & $\begin{array}{c}13.310 \\
(3.048)^{* * *} \\
{[2.713]^{* * *}}\end{array}$ & $\begin{array}{c}1365.859 \\
(369.804)^{* * * *} \\
{[286.887]^{* * * *}}\end{array}$ & $\begin{array}{c}0.206 \\
(0.083)^{* *} \\
{[0.152]}\end{array}$ & $\begin{array}{c}12.901 \\
(3.37)^{* * *} \\
{[3.152]^{* * *}}\end{array}$ & $\begin{array}{c}4.853 \\
(1.76)^{* * *} \\
{[1.023]^{* * *}}\end{array}$ \\
\hline $\begin{array}{l}R^{2} \\
\text { Panel D: Cubic polynomial in la }\end{array}$ & $\begin{array}{r}0.27 \\
\text { longitude }\end{array}$ & 0.39 & 0.23 & 0.3 & 0.21 \\
\hline Castilian part of Andalusia & $\begin{array}{c}9.441 \\
(3.405)^{* * *} \\
{[3.73]^{* *}}\end{array}$ & $\begin{array}{c}1136.215 \\
(391.143)^{* * * *} \\
{[348.083]^{* * * *}}\end{array}$ & $\begin{array}{c}0.060 \\
(0.116) \\
{[0.227]}\end{array}$ & $\begin{array}{c}9.519 \\
(4.26)^{* *} \\
{[4.263]^{* *}}\end{array}$ & $\begin{array}{l}3.346 \\
(2.207) \\
{[2.968]}\end{array}$ \\
\hline$R^{2}$ & 0.31 & 0.46 & 0.32 & 0.36 & 0.26 \\
\hline \multicolumn{6}{|c|}{ Panel E: Cubic polynomial in distance to the Frontier } \\
\hline Castilian part of Andalusia & $\begin{array}{c}10.571 \\
(2.814)^{* * * *} \\
{[2.473]^{* * * *}}\end{array}$ & $\begin{array}{c}1096.695 \\
(319.741)^{* * * *} \\
{[346.411]^{* * *}}\end{array}$ & $\begin{array}{c}0.249 \\
(0.07)^{* * *} \\
{[0.10]^{* *}}\end{array}$ & $\begin{array}{c}9.453 \\
(2.679)^{* * *} \\
{[2.301]^{* * *}}\end{array}$ & $\begin{array}{c}4.216 \\
(1.507)^{* * *} \\
{[0.956]^{* * *}}\end{array}$ \\
\hline$R^{2}$ & 0.26 & 0.38 & 0.24 & 0.29 & 0.23 \\
\hline \multicolumn{6}{|c|}{ Panel F: Cubic polynomial in distance to Madrid } \\
\hline Castilian part of Andalusia & $\begin{array}{c}14.252 \\
(2.987)^{* * *} \\
{[2.464]^{* * *}}\end{array}$ & $\begin{array}{c}1398.948 \\
(356.857)^{* * *} \\
{[327.573]^{* * *}}\end{array}$ & $\begin{array}{c}0.243 \\
(0.087)^{* * *} \\
{[0.162]}\end{array}$ & $\begin{array}{c}9.882 \\
(3.231)^{* * *} \\
{[2.068]^{* * *}}\end{array}$ & $\begin{array}{c}4.433 \\
(1.844)^{* *} \\
{[1.065]^{* * *}}\end{array}$ \\
\hline$R^{2}$ & 0.29 & 0.39 & 0.23 & 0.33 & 0.22 \\
\hline Boundary fixed effects & Yes & Yes & Yes & Yes & Yes \\
\hline Geog.-climatic controls & Yes & Yes & Yes & Yes & Yes \\
\hline Number of observations & 202 & 156 & 208 & 208 & 208 \\
\hline
\end{tabular}

Notes: Variables descriptions are provided in Table A1. Sample restricted to municipalities within $25 \mathrm{~km}$ of the frontier. The set of geographic-climatic controls includes altitude, ruggedness, soil quality, rainfall, temperature and a coast dummy. Robust standard errors are in parentheses, and standard errors corrected for spatial dependence are in brackets. *, ** and *** denote statistical significance at the 10,5 and $1 \%$ level, respectively. 


\begin{tabular}{|c|c|c|c|c|c|c|c|c|}
\hline \multirow{3}{*}{ Dependent variable } & \multirow[b]{2}{*}{$\begin{array}{l}\text { Utilized } \\
\text { agricultural } \\
\text { area }\end{array}$} & \multirow[b]{2}{*}{$\begin{array}{c}\text { Large estate } \\
\text { dummy }(\geq 200 \\
\text { ha) }\end{array}$} & \multicolumn{2}{|c|}{ Individual controls } & \multicolumn{2}{|c|}{ Geog.-climatic controls } & \multicolumn{2}{|c|}{$\begin{array}{c}\text { Preexisting land uses }\left(10^{\text {th }} \text { to }\right. \\
\left.12^{\text {th }} \text { centuries }\right)\end{array}$} \\
\hline & & & $\begin{array}{l}\text { Utilized } \\
\text { agricultural } \\
\text { area }\end{array}$ & $\begin{array}{c}\text { Large estate } \\
\text { dummy }(\geq 200 \\
\text { ha) }\end{array}$ & $\begin{array}{l}\text { Utilized } \\
\text { agricultural } \\
\text { area }\end{array}$ & $\begin{array}{c}\text { Large estate } \\
\text { dummy }(\geq 200 \\
\text { ha) }\end{array}$ & $\begin{array}{l}\text { Utilized } \\
\text { agricultural } \\
\text { area }\end{array}$ & $\begin{array}{c}\text { Large estate } \\
\text { dummy }(\geq 200 \\
\text { ha) }\end{array}$ \\
\hline & $(1)$ & $(2)$ & (3) & $(4)$ & $(5)$ & $(6)$ & $(7)$ & $(8)$ \\
\hline \multicolumn{9}{|c|}{ Panel A: OLS-Border specification } \\
\hline $\begin{array}{l}\text { Castilian part of } \\
\text { Andalusia }\end{array}$ & $\begin{array}{c}101.043^{* * * *} \\
(31.94)\end{array}$ & $\begin{array}{c}0.108 * * * \\
(0.028)\end{array}$ & $\begin{array}{l}77.318^{* * * *} \\
(24.411)\end{array}$ & $\begin{array}{l}0.085 * * * \\
(0.025)\end{array}$ & $\begin{array}{l}67.923 * * * \\
(17.071)\end{array}$ & $\begin{array}{c}0.089 * * * \\
(0.022)\end{array}$ & $\begin{array}{l}69.649 * * * \\
(16.741)\end{array}$ & $\begin{array}{l}0.087 * * * \\
(0.021)\end{array}$ \\
\hline$R^{2}$ & 0.10 & 0.06 & 0.25 & 0.12 & 0.26 & 0.14 & 0.26 & 0.14 \\
\hline \multicolumn{9}{|c|}{ Panel B: Quadratic polynomial in latitude and longitude } \\
\hline $\begin{array}{l}\text { Castilian part of } \\
\text { Andalusia }\end{array}$ & $\begin{array}{c}208.231^{* * * *} \\
(78.58)\end{array}$ & $\begin{array}{c}0.167^{* * * *} \\
(0.052)\end{array}$ & $\begin{array}{c}164.703 * * * \\
(51.475)\end{array}$ & $\begin{array}{c}0.131 * * * \\
(0.043)\end{array}$ & $\begin{array}{l}151.829 * * * \\
(44.998)\end{array}$ & $\begin{array}{c}0.114 * * * * \\
(0.034)\end{array}$ & $\begin{array}{c}148.358 * * * \\
(46.879)\end{array}$ & $\begin{array}{c}0.114 * * * \\
(0.034)\end{array}$ \\
\hline$R^{2}$ & 0.16 & 0.09 & 0.28 & 0.15 & 0.31 & 0.16 & 0.32 & 0.16 \\
\hline \multicolumn{9}{|c|}{ Panel C: Quadratic polynomial in distance to the Frontier } \\
\hline $\begin{array}{l}\text { Castilian part of } \\
\text { Andalusia }\end{array}$ & $\begin{array}{l}90.842 * * * \\
(26.985)\end{array}$ & $\begin{array}{c}0.098 * * * \\
(0.025)\end{array}$ & $\begin{array}{l}69.048^{* * * *} \\
(21.349)\end{array}$ & $\begin{array}{l}0.077 * * * \\
(0.023)\end{array}$ & $\begin{array}{l}65.03 * * * \\
(15.915)\end{array}$ & $\begin{array}{c}0.087 * * * * \\
(0.02)\end{array}$ & $\begin{array}{c}67.297 * * * * \\
(15.789)\end{array}$ & $\begin{array}{l}0.085^{* * * *} \\
(0.019)\end{array}$ \\
\hline$R^{2}$ & 0.11 & 0.08 & 0.26 & 0.13 & 0.26 & 0.14 & 0.27 & 0.15 \\
\hline \multicolumn{9}{|c|}{ Panel D: Quadratic polynomial in distance to Madrid } \\
\hline $\begin{array}{l}\text { Castilian part of } \\
\text { Andalusia }\end{array}$ & $\begin{array}{l}129.053^{* * * *} \\
(38.655)\end{array}$ & $\begin{array}{c}0.137 * * * \\
(0.034)\end{array}$ & $\begin{array}{c}92.224^{* * * *} \\
(28.83)\end{array}$ & $\begin{array}{c}0.100 * * * \\
(0.03)\end{array}$ & $\begin{array}{l}107.701 * * * \\
(23.963)\end{array}$ & $\begin{array}{c}0.111^{* * * *} \\
(0.026)\end{array}$ & $\begin{array}{l}108.079 * * * \\
(25.107)\end{array}$ & $\begin{array}{c}0.126 * * * \\
(0.027)\end{array}$ \\
\hline$R^{2}$ & 0.15 & 0.07 & 0.27 & 0.13 & 0.31 & 0.15 & 0.31 & 0.15 \\
\hline Boundary fixed effects & Yes & Yes & Yes & Yes & Yes & Yes & Yes & Yes \\
\hline Individual controls & No & No & Yes & Yes & Yes & Yes & Yes & Yes \\
\hline Geog.-climatic controls & No & No & No & No & Yes & Yes & Yes & Yes \\
\hline Preexisting land uses & No & No & No & No & No & No & Yes & Yes \\
\hline Number of clusters & 203 & 203 & 203 & 203 & 203 & 203 & 203 & 203 \\
\hline Number of observations & 128,628 & 128,628 & 128,628 & 128,628 & 128,628 & 128,628 & 128,628 & 128,628 \\
\hline
\end{tabular}


TABLE 6. THE EFFECT OF THE FRONTIER ON CONTEMPORARY OUTCOMES: A 2SLS MODEL

\begin{tabular}{|c|c|c|c|c|c|c|c|c|c|}
\hline Outcome variable $\rightarrow$ & $\begin{array}{l}\text { Average } \\
\text { socio- } \\
\text { economic } \\
\text { condition }\end{array}$ & $\begin{array}{l}\text { Number of } \\
\text { cars over } \\
\text { population }\end{array}$ & $\begin{array}{l}\text { Education } \\
\text { level of } \\
\text { population } \\
\text { 30-39 years }\end{array}$ & $\begin{array}{c}\text { Employment } \\
\text { in industry } \\
\text { and services } \\
(\%)\end{array}$ & $\begin{array}{c}\text { Long-term } \\
\text { population } \\
\text { growth 1950- } \\
2010(\%)\end{array}$ & $\begin{array}{l}\text { Changes in } \\
\text { the local } \\
\text { government } \\
\text { since } 1979\end{array}$ & $\begin{array}{l}\text { Number of } \\
\text { political } \\
\text { parties that } \\
\text { have } \\
\text { controlled the } \\
\text { town council }\end{array}$ & $\begin{array}{c}\text { Local } \\
\text { public } \\
\text { debt per } \\
\text { capita }\end{array}$ & $\begin{array}{l}\text { Average } \\
\text { immigration } \\
\text { rate 1988- } \\
2014\end{array}$ \\
\hline & (1) & (2) & (3) & (4) & (5) & (6) & (7) & (8) & (9) \\
\hline
\end{tabular}

Panel A: Without polynomial indicating geographic location

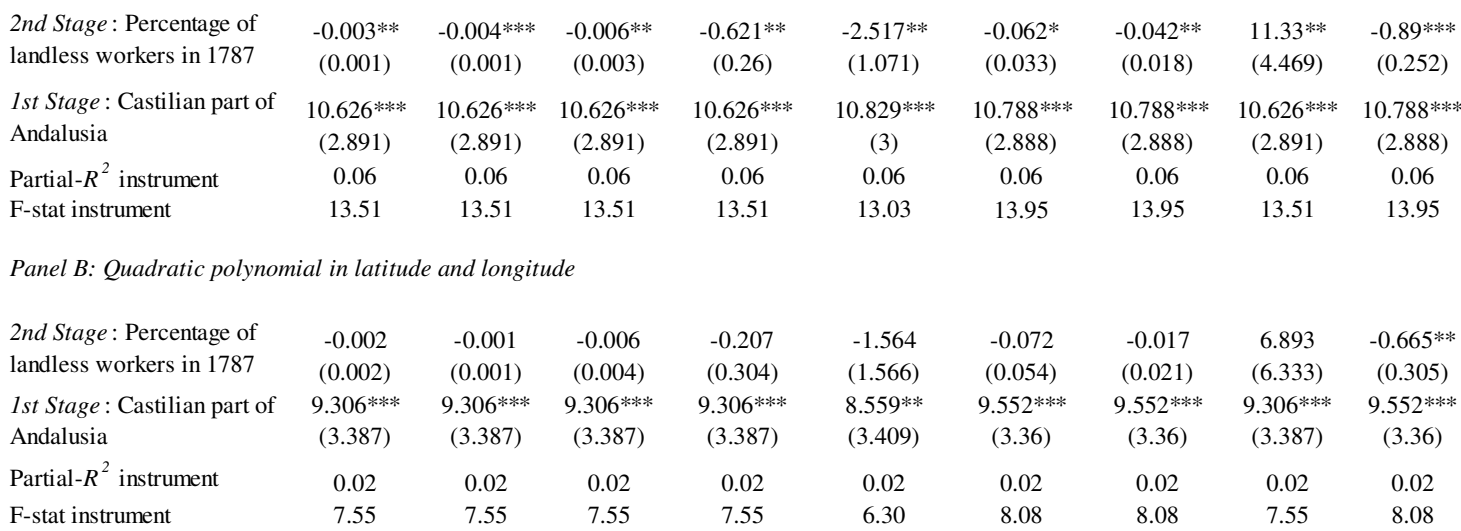

Panel C: Quadratic polynomial in distance to the Frontier

\begin{tabular}{|c|c|c|c|c|c|c|c|c|c|}
\hline $\begin{array}{l}\text { 2nd Stage: Percentage of } \\
\text { landless workers in } 1787\end{array}$ & $\begin{array}{l}-0.003^{* *} \\
(0.001)\end{array}$ & $\begin{array}{c}-0.004 * * * \\
(0.001)\end{array}$ & $\begin{array}{c}-0.007 * * \\
(0.003)\end{array}$ & $\begin{array}{c}-0.651^{* *} \\
(0.268)\end{array}$ & $\begin{array}{l}-2.324 * * \\
(1.015)\end{array}$ & $\begin{array}{l}-0.071 * * \\
(0.035)\end{array}$ & $\begin{array}{l}-0.045^{* *} \\
(0.019)\end{array}$ & $\begin{array}{c}12.004 * * \\
(4.669)\end{array}$ & $\begin{array}{l}-0.84 * * * \\
(0.248)\end{array}$ \\
\hline $\begin{array}{l}\text { 1st Stage: Castilian part of } \\
\text { Andalusia }\end{array}$ & $\begin{array}{l}10.375^{* * *} \\
(2.843)\end{array}$ & $\begin{array}{l}10.375^{* * *} \\
(2.843)\end{array}$ & $\begin{array}{c}10.375^{* * * *} \\
(2.843)\end{array}$ & $\begin{array}{c}10.375^{* * * *} \\
(2.843)\end{array}$ & $\begin{array}{l}10.507 * * * \\
(2.948)\end{array}$ & $\begin{array}{l}10.523 * * * \\
(2.838)\end{array}$ & $\begin{array}{c}10.523 * * * \\
(2.838)\end{array}$ & $\begin{array}{c}10.375^{* * *} \\
(2.843)\end{array}$ & $\begin{array}{c}10.523^{* * *} \\
(2.838)\end{array}$ \\
\hline Partial- $R^{2}$ instrument & 0.06 & 0.06 & 0.06 & 0.06 & 0.06 & 0.06 & 0.06 & 0.06 & 0.06 \\
\hline F-stat instrument & 13.31 & 13.31 & 13.31 & 13.31 & 12.70 & 13.75 & 13.75 & 13.31 & 13.75 \\
\hline \multicolumn{10}{|c|}{ Panel D: Quadratic polynomial in distance to Madrid } \\
\hline $\begin{array}{l}\text { 2nd Stage: Percentage of } \\
\text { landless workers in } 1787\end{array}$ & $\begin{array}{l}-0.002 * \\
(0.001)\end{array}$ & $\begin{array}{c}-0.002 * * * \\
(0.001)\end{array}$ & $\begin{array}{c}-0.004 * * \\
(0.002)\end{array}$ & $\begin{array}{l}-0.229 \\
(0.176)\end{array}$ & $\begin{array}{l}-2.229 * * * \\
(0.854)\end{array}$ & $\begin{array}{l}-0.051 * \\
(0.027)\end{array}$ & $\begin{array}{l}-0.023 * \\
(0.012)\end{array}$ & $\begin{array}{c}3.615 \\
(2.815)\end{array}$ & $\begin{array}{c}-0.689 * * * \\
(0.171)\end{array}$ \\
\hline $\begin{array}{l}\text { 1st Stage: Castilian part of } \\
\text { Andalusia }\end{array}$ & $\begin{array}{l}14.952 * * * \\
(3.141)\end{array}$ & $\begin{array}{c}14.952 * * * \\
(3.141)\end{array}$ & $\begin{array}{c}14.952 * * * \\
(3.141)\end{array}$ & $\begin{array}{c}14.952^{* * * *} \\
(3.141)\end{array}$ & $\begin{array}{c}14.587 * * * \\
(3.156)\end{array}$ & $\begin{array}{l}15.119^{* * *} \\
(3.134)\end{array}$ & $\begin{array}{c}15.119^{* * *} \\
(3.134)\end{array}$ & $\begin{array}{c}14.952^{* * *} \\
(3.141)\end{array}$ & $\begin{array}{c}15.119 \text { *** } \\
(3.134)\end{array}$ \\
\hline Partial- $R^{2}$ instrument & 0.08 & 0.08 & 0.08 & 0.08 & 0.08 & 0.09 & 0.09 & 0.08 & 0.09 \\
\hline F-stat instrument & 22.66 & 22.66 & 22.66 & 22.66 & 21.37 & 23.27 & 23.27 & 22.66 & 23.27 \\
\hline Boundary fixed effects & Yes & Yes & Yes & Yes & Yes & Yes & Yes & Yes & Yes \\
\hline Geog.-climatic controls & Yes & Yes & Yes & Yes & Yes & Yes & Yes & Yes & Yes \\
\hline Number of observations & 201 & 201 & 201 & 201 & 194 & 202 & 202 & 201 & 202 \\
\hline $\begin{array}{l}\text { Average value of the } \\
\text { outcome variable }\end{array}$ & 0.76 & 0.29 & 2.41 & 75.68 & -15.63 & 3.16 & 2.71 & 232.40 & 26.82 \\
\hline
\end{tabular}

Notes: 2SLS regressions, in which the left-hand side variable is the percentage of landless workers in 1787 in the first stage, and as indicated in the headings in the second stage. The coefficients on the relevant variables in each stage are shown in the entries. Variables descriptions are provided in Table A1. Sample restricted to municipalities within $25 \mathrm{~km}$ of the frontier. The set of geographic-climatic controls includes altitude, ruggedness, soil quality, rainfall, temperature and a coast dummy. Robust standard errors are in parentheses. $*$, ** and $* * *$ denote statistical significance at the 10,5 and $1 \%$ level, respectively. 


\begin{tabular}{|c|c|c|}
\hline Variable & Description & Source \\
\hline \multicolumn{3}{|l|}{ Dependent variables } \\
\hline $\begin{array}{l}\text { Gini index of land } \\
\text { distribution }\end{array}$ & $\begin{array}{l}\text { The Gini index of utilized agricultural area (UAA) in } 1982 \text {. We focus } \\
\text { on private agricultural holdings (with legal status of natural person or } \\
\text { company), which represent } 95 \% \text { of total UAA. This variable is } \\
\text { multiplied by } 100 \text { so that values range from } 0 \text { to } 100 \text {. }\end{array}$ & $\begin{array}{l}\text { Authors' elaboration using the } 1982 \\
\text { agricultural census (Instituto Nacional } \\
\text { de Estadística -INE-, 1982). }\end{array}$ \\
\hline $\begin{array}{l}\text { Land concentration in } \\
\text { holdings } \geq 200 \text { ha }\end{array}$ & $\begin{array}{l}\text { Percentage of UAA in holdings equal to or greater than } 200 \text { hectares of } \\
\text { UAA, in } 1982 \text {. We focus on private agricultural holdings (with legal } \\
\text { status of natural person or company), which represent } 95 \% \text { of total } \\
\text { UAA. }\end{array}$ & $\begin{array}{l}\text { Authors' elaboration using the } 1982 \\
\text { agricultural census (INE, 1982). }\end{array}$ \\
\hline Mayor Hacendado/Surface & $\begin{array}{l}\text { Total amount of income earned by the individual that in each } \\
\text { municipality earns the highest income in the middle of the } 18^{\text {th }} \text { century } \\
\text { (between } 1750 \text { and } 1753 \text { ), divided by the surface area of the } \\
\text { municipality. }\end{array}$ & $\begin{array}{l}\text { Catastro de Ensenada-Books of El } \\
\text { Mayor Hacendado (1750-1753). }\end{array}$ \\
\hline $\begin{array}{l}\text { Privileged Orders } \\
\text { jurisdiction }\end{array}$ & $\begin{array}{l}\text { Dummy variable indicating whether the jurisdiction of the municipality } \\
\text { at the end of the } 18^{\text {th }} \text { century (1787) belonged to the nobility, the } \\
\text { military orders or the Church. }\end{array}$ & $\begin{array}{l}\text { Authors' elaboration using the } 1787 \\
\text { population census (INE, 1987). }\end{array}$ \\
\hline $\begin{array}{l}\text { Percentage of landless } \\
\text { workers }\end{array}$ & $\begin{array}{l}\text { Percentage of landless workers over the total active agricultural } \\
\text { population in } 1787 \text {, where the total agricultural population is } \\
\text { composed of farmers and landless day laborers. }\end{array}$ & $\begin{array}{l}\text { Authors' elaboration using the } 1787 \\
\text { population census (INE, 1987). }\end{array}$ \\
\hline \multicolumn{3}{|l|}{ Independent variables } \\
\hline Altitude & Average altitude in meters, computed using GIS software. & $\begin{array}{l}\text { Authors' elaboration using geo- } \\
\text { referenced data from Hijmans et al. } \\
(2005) \text {. }\end{array}$ \\
\hline $\begin{array}{l}\text { Arable land (\% surface } \\
\text { area) }\end{array}$ & $\begin{array}{l}\text { Percentage of arable land over the total surface area, corresponding to } \\
\text { the } 1982 \text { agricultural census. }\end{array}$ & $\begin{array}{l}\text { Instituto de Estadística y Cartografía } \\
\text { de Andalucía -IECA- (2014b). }\end{array}$ \\
\hline Aridity & $\begin{array}{l}\text { Average aridity of the municipality surface area, corresponding to the } \\
\text { period 1950-2000. The indicator ranges from } 0 \text { to } 1 \text {, with higher } \\
\text { values indicating more humid conditions. It is computed using GIS } \\
\text { software. }\end{array}$ & $\begin{array}{l}\text { Authors' elaboration using geo- } \\
\text { referenced data Trabucco and Zomer } \\
(2009) \text {. }\end{array}$ \\
\hline Castilian part of Andalusia & $\begin{array}{l}\text { Dummy variable indicating whether the municipality belonged to the } \\
\text { Castilian part of Andalusia. }\end{array}$ & $\begin{array}{l}\text { Authors' elaboration using maps from } \\
\text { Instituto de Cartografía de Andalucía } \\
(2009) \text {. }\end{array}$ \\
\hline Coast dummy & $\begin{array}{l}\text { Dummy variable indicating whether the municipality has access to the } \\
\text { coast. }\end{array}$ & Authors' elaboration. \\
\hline $\begin{array}{l}\text { Conquered during the } 14 \text { th } \\
\text { Century/ Conquered during } \\
\text { the } 15 \text { th Century }\end{array}$ & $\begin{array}{l}\text { Dummy variables indicating whether the municipality was conquered } \\
\text { during the 14th Century, or during the 15th Century (prior to the } \\
\text { beginning of the War of Granada [1481-1492]). }\end{array}$ & $\begin{array}{l}\text { Mestre-Campi and Sabate (1998), } \\
\text { official web pages of municipalities, } \\
\text { and the tourism website of the } \\
\text { Andalusian Government } \\
\text { (http://www.andalucia.org/). }\end{array}$ \\
\hline Crops (\% surface area) & $\begin{array}{l}\text { Percentage of land devoted to herbaceous crops over the total surface } \\
\text { area, corresponding to the } 1982 \text { agricultural census. }\end{array}$ & $\operatorname{IECA}(2014 b)$ \\
\hline Distance to the frontier & $\begin{array}{l}\text { Linear distance between the centroid of the municipality and the } \\
\text { closest point of the former Frontier of Granada (in meters), computed } \\
\text { using GIS software. The frontier of Granada is defined as it was at the } \\
\text { beginning of the War of Granada (1481-1492). }\end{array}$ & $\begin{array}{l}\text { Authors' elaboration using maps from } \\
\text { Instituto de Cartografía de Andalucía } \\
(2009) \text {. }\end{array}$ \\
\hline Distance to Madrid & $\begin{array}{l}\text { Linear distance between the centroid of the municipality and Madrid } \\
\text { (in meters), computed using GIS software. }\end{array}$ & Authors' elaboration. \\
\hline $\begin{array}{l}\text { Distance to urban centers in } \\
1200 \text { and in } 1400\end{array}$ & $\begin{array}{l}\text { Distance to urban centers in } 1200 \text { and } 1400 \text { (in kilometers), } \\
\text { considering an urban center that having at least } 5000 \text { inhabitants at } \\
\text { some time between } 800 \text { and } 1800 \text {. It is computed using GIS software. }\end{array}$ & $\begin{array}{l}\text { Authors' elaboration using } \\
\text { information from Bairoch (1988). }\end{array}$ \\
\hline $\begin{array}{l}\text { Fine soil texture (\% surface } \\
\text { area) }\end{array}$ & $\begin{array}{l}\text { Percentage of land for which the dominant surface textural class is fine } \\
(35 \%<\text { clay }<60 \%) \text {, computed using GIS software. }\end{array}$ & $\begin{array}{l}\text { Authors' elaboration using geo- } \\
\text { referenced data from Panagos et a. } \\
\text { (2012), Liedekerke et al. (2006) and } \\
\text { Panagos (2006). }\end{array}$ \\
\hline Latitude & $\begin{array}{l}\text { Latitude (in decimal degrees) corresponding to the centroid of the } \\
\text { municipality urban center. }\end{array}$ & $\begin{array}{l}\text { Geographic Nomenclature of } \\
\text { Municipalities and Local Population } \\
\text { (IGN, 2012). }\end{array}$ \\
\hline
\end{tabular}


TABLE A1 - DESCRIPTION OF VARIABLES (Continued)

\begin{tabular}{|c|c|c|}
\hline Variable & Description & Source \\
\hline Longitude & $\begin{array}{l}\text { Longitude (in decimal degrees) corresponding to the centroid of the } \\
\text { municipality urban center. }\end{array}$ & $\begin{array}{l}\text { Geographic Nomenclature of } \\
\text { Municipalities and Local Population } \\
\text { (IGN, 2012). }\end{array}$ \\
\hline $\begin{array}{l}\text { Low topsoil carbon }(\% \\
\text { surface area })\end{array}$ & $\begin{array}{l}\text { Percentage of area with low or very low topsoil carbon content, } \\
\text { computed using GIS software. }\end{array}$ & $\begin{array}{l}\text { Authors' elaboration using geo- } \\
\text { referenced data from Panagos et a. } \\
\text { (2012), Liedekerke et al. (2006) and } \\
\text { Panagos (2006). }\end{array}$ \\
\hline $\begin{array}{l}\text { Preexisting land uses }\left(10^{\text {th }}\right. \\
\left.\text { to } 12^{\text {th }} \text { centuries }\right)\end{array}$ & $\begin{array}{l}\text { Four indicators indicating the percentage of surface area in each } \\
\text { municipality made up of: i) forest, ii) intensive agriculture and } \\
\text { irrigation, iii) non-intensive agriculture, and iv) pastureland, in al- }\end{array}$ & $\begin{array}{l}\text { Authors' elaboration using maps from } \\
\text { Instituto de Cartografía de Andalucía } \\
\text { (2009). }\end{array}$ \\
\hline Presence of Roman roads & $\begin{array}{l}\text { Andalus times }\left(10^{\text {th }} \text { to } 12^{\text {th }} \text { centuries }\right) \text {. It is computed using GIS } \\
\text { software. } \\
\text { Dummy variable indicating whether any Roman road passes through } \\
\text { the municipality surface area, computed using GIS software. }\end{array}$ & $\begin{array}{l}\text { Authors' elaboration using geo- } \\
\text { referenced data from McCormick et } \\
\text { al. (2013). }\end{array}$ \\
\hline Rainfall & $\begin{array}{l}\text { Annual precipitation. It is expressed in hundreds of millimeters, except } \\
\text { in Table } 2 \text { where it is expressed in millimeters. }\end{array}$ & $\begin{array}{l}\text { Authors' elaboration using geo- } \\
\text { referenced data from IECA ( } 2014 \mathrm{a}) \text {. }\end{array}$ \\
\hline Ruggedness & Standard deviation of altitude in meters, computed using GIS software. & $\begin{array}{l}\text { Authors' elaboration using geo- } \\
\text { referenced data from Hijmans et al. } \\
(2005) \text {. }\end{array}$ \\
\hline Soil quality & $\begin{array}{l}\text { Indicator of soil quality calculated as: } 4 *(\% \text { surface area with } \\
\text { excellent soil capacity })+3 *(\% \text { surface area with good soil capacity }) \\
+2 *(\% \text { surface area with moderate soil capacity })+1 *(\% \text { surface area } \\
\text { with marginal soil capacity }) \text {, with values ranging from } 1 \text { (low soil } \\
\text { quality) to } 4 \text { (excellent soil quality). It is computed using GIS } \\
\text { software. }\end{array}$ & $\begin{array}{l}\text { Consejería de Medio Ambiente. Junta } \\
\text { de Andalucía (1996). }\end{array}$ \\
\hline $\begin{array}{l}\text { Surface area with a steep } \\
\text { slope }(\%)\end{array}$ & $\begin{array}{l}\text { Percentage of surface area with a steep slope (higher than or equal to } \\
15 \text { percent). }\end{array}$ & IECA (2014b). \\
\hline $\begin{array}{l}\text { Mediterranean phytoclimate } \\
(\%)\end{array}$ & $\begin{array}{l}\text { Percentage of surface area corresponding to Mediterranean } \\
\text { phytoclimate, which is related to specific potential types of vegetation } \\
\text { such as Quercus ilex rotundifolia or Quercus ilex ilex. It is computed } \\
\text { using GIS software. }\end{array}$ & $\begin{array}{l}\text { Authors' elaboration using geo- } \\
\text { referenced data from Allué (1990). }\end{array}$ \\
\hline $\begin{array}{l}\text { Moderate or high erodibility } \\
(\% \text { surface area) }\end{array}$ & $\begin{array}{l}\text { Percentage of surface area with moderate or high erodibility, } \\
\text { computed using GIS software. }\end{array}$ & $\begin{array}{l}\text { Authors' elaboration using geo- } \\
\text { referenced data from Panagos et a. } \\
\text { (2012), Liedekerke et al. (2006) and } \\
\text { Panagos (2006). }\end{array}$ \\
\hline Temperature & Annual average temperature (in degrees Celsius). & $\begin{array}{l}\text { Authors' elaboration using geo- } \\
\text { referenced data from IECA (2014a). }\end{array}$ \\
\hline $\begin{array}{l}\text { Years under the frontier } \\
\text { effect }\end{array}$ & $\begin{array}{l}\text { Number of years between the conquest of the municipality by Castile } \\
\text { and the beginning of the War of Granada (1481-1492). Municipalities } \\
\text { conquered during the War of Granada have a value equal to } 0 .\end{array}$ & $\begin{array}{l}\text { Mestre-Campi and Sabate (1998), } \\
\text { official web pages of municipalities, } \\
\text { and the tourism website of the } \\
\text { Andalusian Government } \\
\text { (http://www.andalucia.org/). }\end{array}$ \\
\hline \multicolumn{3}{|c|}{ Contemporary outcomes indicators } \\
\hline $\begin{array}{l}\text { Average socioeconomic } \\
\text { condition }\end{array}$ & $\begin{array}{l}\text { Average of class marks of socioeconomic conditions of individuals, } \\
\text { combining information from occupation, activity and professional } \\
\text { situation. To illustrate the construction of this variable, a (maximum) } \\
\text { class mark of } 3 \text { is given to non-agricultural entrepreneurs with } \\
\text { employees, and a (minimun) class mark of } 0 \text { to those unemployed who } \\
\text { have not worked previously. Year } 2001 \text {. }\end{array}$ & $\begin{array}{l}\text { Censos de Población y Viviendas, } \\
\text { INE (2001). }\end{array}$ \\
\hline $\begin{array}{l}\text { Number of cars over } \\
\text { population }\end{array}$ & Cars registered in the municipality over population. Year 2001. & $\operatorname{IECA}(2014 b)$. \\
\hline $\begin{array}{l}\text { Education level of } \\
\text { population } 30-39 \text { years }\end{array}$ & $\begin{array}{l}\text { Average of class marks of the education level of individuals, with } \\
\text { class marks ranging from } 0 \text { (illiterate) to } 4.5(\mathrm{PhD}) \text {. Year } 2001 .\end{array}$ & $\begin{array}{l}\text { Censos de Población y Viviendas, } \\
\text { INE (2001). }\end{array}$ \\
\hline $\begin{array}{l}\text { Employment in industry and } \\
\text { services }(\%)\end{array}$ & $\begin{array}{l}\text { Percentage of workers in the industrial and service sectors over the } \\
\text { total economy. }\end{array}$ & $\begin{array}{l}\text { Censos de Población y Viviendas, } \\
\text { INE (2001). }\end{array}$ \\
\hline
\end{tabular}


TABLE A1 - DESCRIPTION OF VARIABLES (Continued)

\begin{tabular}{|c|c|c|}
\hline Variable & Description & Source \\
\hline $\begin{array}{l}\text { Long-term population } \\
\text { growth } 1950-2010\end{array}$ & Population growth over the period $1950-2010$. & $\begin{array}{l}1950 \text { population census and } 2010 \\
\text { municipal census, INE (ww.ine.es) }\end{array}$ \\
\hline $\begin{array}{l}\text { Changes in the local } \\
\text { government since } 1979\end{array}$ & $\begin{array}{l}\text { Number of changes (alternation) in the political party of the town } \\
\text { mayor since the first local democratic elections in } 1979 \text { (until 2014). }\end{array}$ & $\begin{array}{l}\text { Database of Mayors, Ministerio de } \\
\text { Hacienda y Administraciones } \\
\text { Públicas (2015a). }\end{array}$ \\
\hline $\begin{array}{l}\text { Number of political parties } \\
\text { that have controlled the town } \\
\text { council }\end{array}$ & $\begin{array}{l}\text { Number of different political parties that have controlled the town } \\
\text { council since the first local democratic elections in } 1979 \text { (until 2014). }\end{array}$ & $\begin{array}{l}\text { Database of Mayors, Ministerio de } \\
\text { Hacienda y Administraciones } \\
\text { Públicas (2015a). }\end{array}$ \\
\hline Local public debt per capita & $\begin{array}{l}\text { Debt of the town council with financial entities divided by population. } \\
\text { Year } 2008 \text { (first year of availability of data). }\end{array}$ & $\begin{array}{l}\text { Debt of Local Authorities, Ministerio } \\
\text { de Hacienda y Administraciones } \\
\text { Públicas (2015b). }\end{array}$ \\
\hline $\begin{array}{l}\text { Average immigration rate } \\
1988-2014\end{array}$ & $\begin{array}{l}\text { Average immigration rate during the period } 1988-2014 \text {. Immigration } \\
\text { rate is equal to the number of people entering the municipality each } \\
\text { year per } 1,000 \text { inhabitants. }\end{array}$ & IECA (2014b). \\
\hline \multicolumn{3}{|c|}{ Variables at the agricultural holding level } \\
\hline Utilized agricultural area & $\begin{array}{l}\text { UAA of the agricultural holding measured in hectares. We only } \\
\text { consider private agricultural holdings (with legal status of natural } \\
\text { person or company). }\end{array}$ & $\begin{array}{l}\text { Authors' elaboration using the } 1982 \\
\text { agricultural census (INE, 1982). }\end{array}$ \\
\hline $\begin{array}{l}\text { Large estate dummy }(>=200 \\
\text { ha) }\end{array}$ & $\begin{array}{l}\text { Dummy variable indicating whether the agricultural holding is equal to } \\
\text { or greater than } 200 \text { ha in UAA. We only consider private agricultural } \\
\text { holdings (with legal status of natural person or company). }\end{array}$ & $\begin{array}{l}\text { Authors' elaboration using the } 1982 \\
\text { agricultural census (INE, 1982). }\end{array}$ \\
\hline Individual controls & $\begin{array}{l}\text { Individual controls are "company" (whether the holding is managed by } \\
\text { a company rather than by a natural person), "utilized agricultural area } \\
\text { over total surface area (\%)", "pastureland" (whether the holding has } \\
\text { no arable land), and a set of dummies indicating the type of tenure } \\
\text { system. }\end{array}$ & $\begin{array}{l}\text { Authors' elaboration using the } 1982 \\
\text { agricultural census (INE, 1982). }\end{array}$ \\
\hline
\end{tabular}

Notes and additional references:

The basic layer with the administrative limits of the Andalusian municipalities, used in the variables computed with GIS software, comes from IECA (2014a).

Allué, J. L., 1990. Mapa de Subregiones Fitoclimáticas de España Peninsular y Balear. Dirección General de Medio Natural y Política Forestal. Ministerio de Medio Ambiente, y Medio Rural y Marino.

Press.

Hijmans, R.J., S.E. Cameron, J.L. Parra, P.G. Jones and A. Jarvis, 2005. "Very high resolution interpolated climate surfaces for global land areas." International Journal of Climatology 25: 1965-1978.

Consejería de Medio Ambiente, 1996. Mapa de Capacidad de Uso General y Erosión de las tierras de Andalucía a escala 1:400.000.

Consejería de Medio Ambiente. Junta de Andalucía. Año 1996.

Instituto de Estadística y Cartografía de Andalucía, 2014a. Datos Espaciales de Referencia de Andalucía. Available at

http://www.juntadeandalucia.es/institutodeestadisticaycartografia/

Instituto de Estadística y Cartografía de Andalucía, 2014b. Sistema de Información Multiterritorial de Andalucía. Available at http://www.juntadeandalucia.es/institutodeestadisticaycartografia/

Instituto Geográfico Nacional, 2014. Nomenclátor Geográfico de Municipios y Entidades de Población. Available at http://www.ign.es/

Instituto Nacional de Estadística, 1982. Censo Agrario de 1982. Microdatos. Available at http://www.ine.es/

Instituto Nacional de Estadística, 1987. Censo de 1787 "Floridablanca". Tomo I, Prolegómenos; Comunidades autónomas meridionales . Madrid:Instituto Nacional de Estadística.

Instituto Nacional de Estadística, 2001. Censos de Población y Viviendas 2001. Available at www.ine.es.

Ministerio de Hacienda y Administraciones Públicas (2015a). Base de datos de Alcaldes. Elecciones 1979 - 2015. Available at

http://www.seap.minhap.gob.es/

Ministerio de Hacienda y Administraciones Públicas (2015b). Deuda Viva de las Entidades Locales. Available at

http://www.minhap.gob.es/

McCormick, Michael , Guoping Huang, Giovanni Zambotti and Jessica Lavash, 2013. "Roman Road Network (version 2008)." DARMC

Scholarly Data Series, Data Contribution Series \#2013-5. DARMC, Center for Geographic Analysis, Harvard University, Cambridge MA 02138.

Panagos, Panos, 2006. “The European soil database.” GEO: connexion, 5 (7), 32-33.

Panagos, Panos, Marc Van Liedekerke, Arwyn Jones and L. Montanarella, 2012. "European Soil Data Centre: Response to European policy support and public data requirements." Land Use Policy, 29 (2), 329-338.

Trabucco, A., and Zomer, R.J. 2009. Global Aridity Index (Global-Aridity) and Global Potential Evapo-Transpiration (Global-PET) Geospatial Database. CGIAR Consortium for Spatial Information. Published online, available from the CGIAR-CSI GeoPortal at: http://www.csi.cgiar.org.

Van Liedekerke, Marc Van, Arwyn Jones and Panos Panagos, 2006. ESDBv2 Raster Library - a set of rasters derived from the European Soil Database distribution v2.0. European Commission and the European Soil Bureau Network, CD-ROM. 


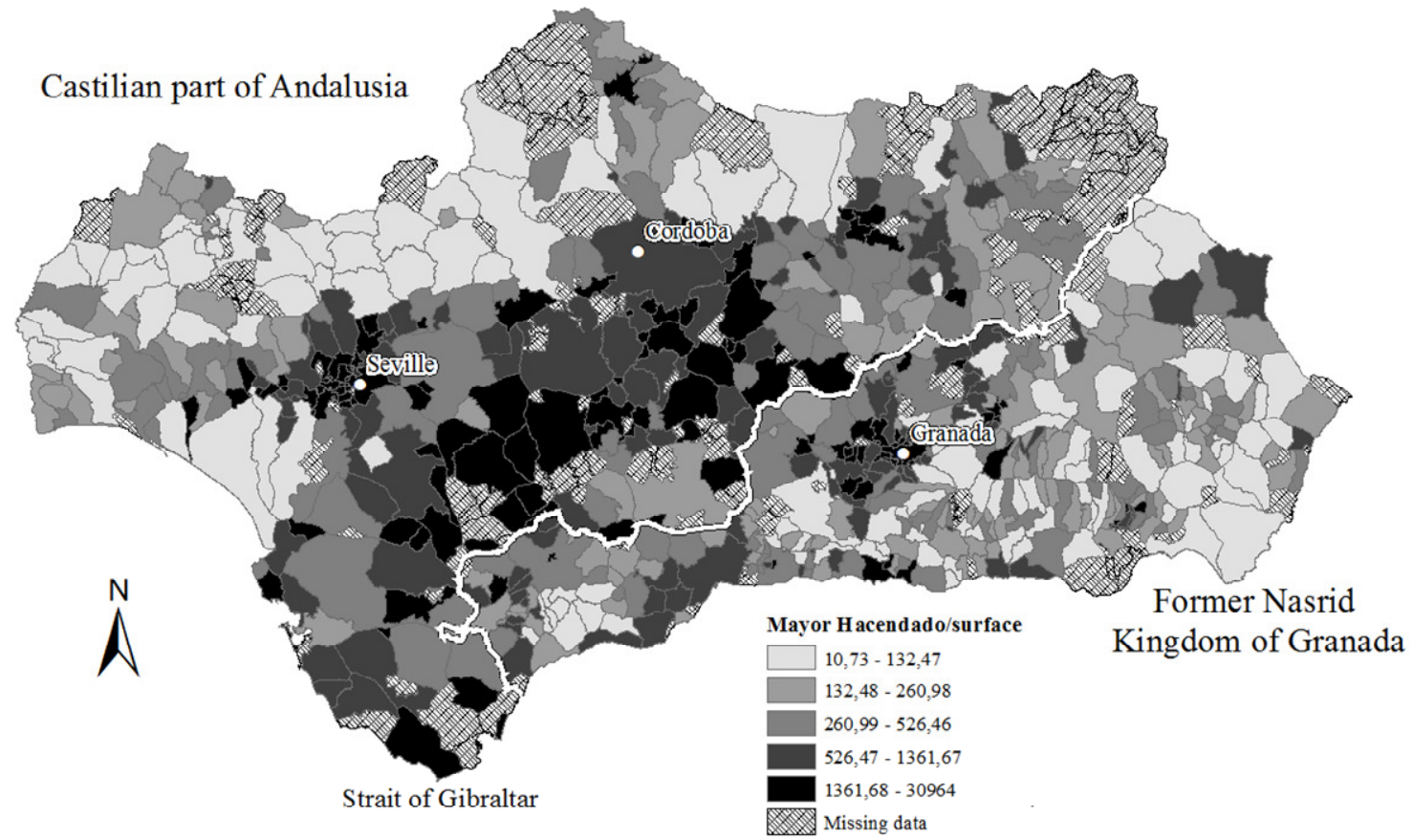

Figure 3. Andalusia, the frontier of Granada and "Mayor hacendado/surface" in the 1750s

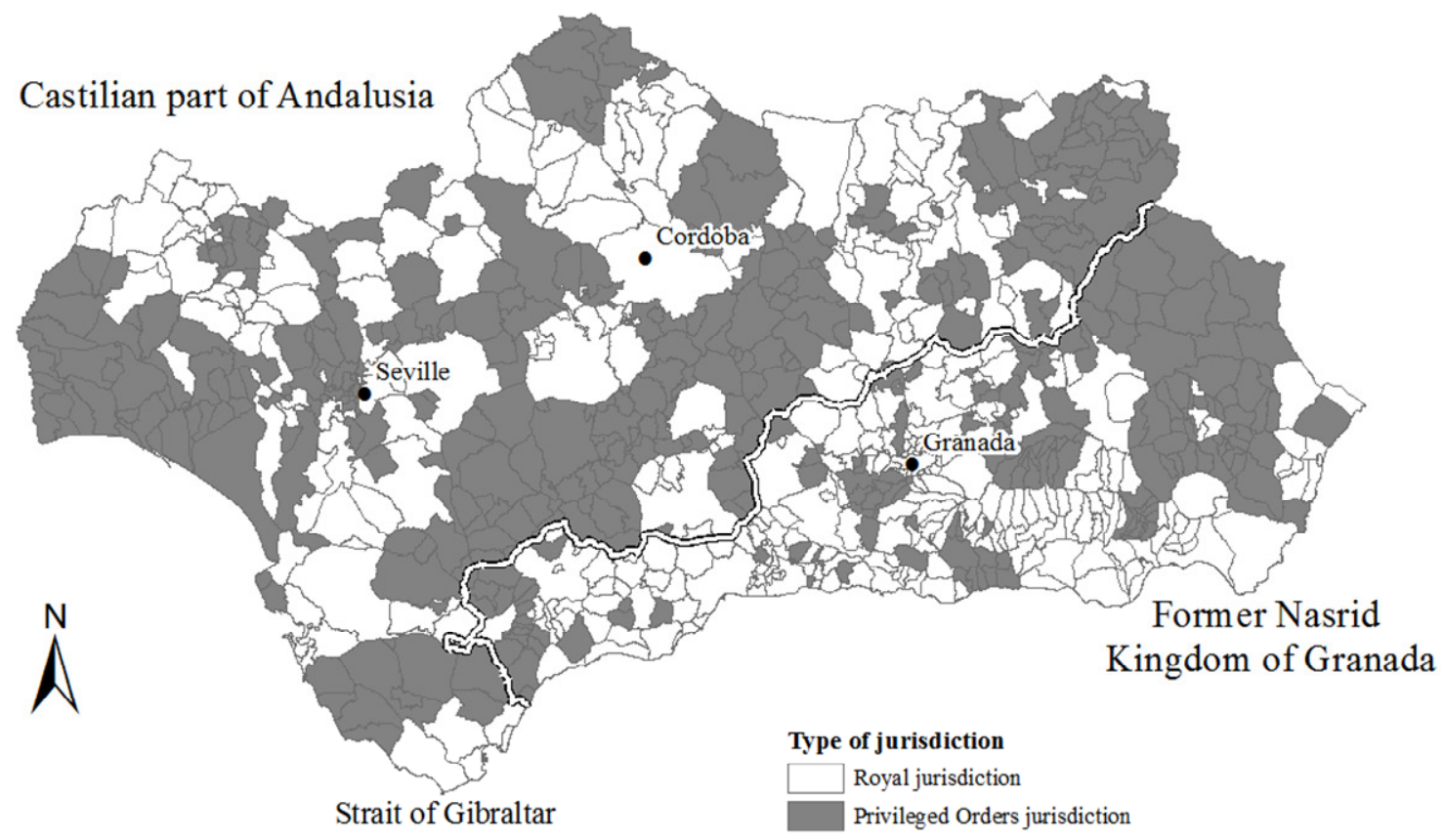

Figure 4. Andalusia, the frontier of Granada and Privileged Orders jurisdiction in 1787 


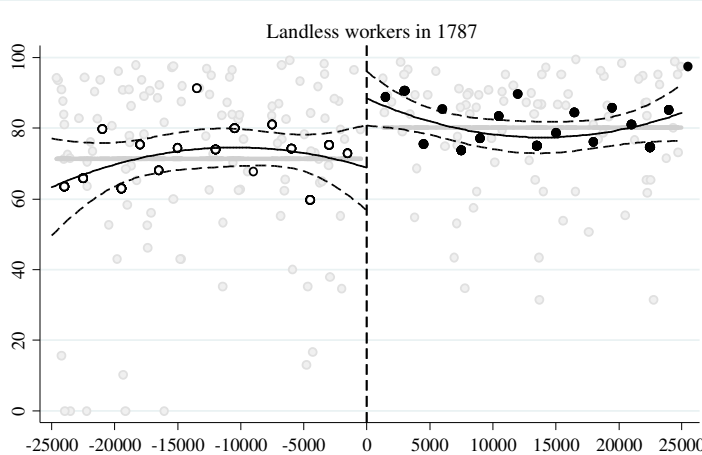

Distance to the frontier in meters (Former Kingdom of Granada in negative values)

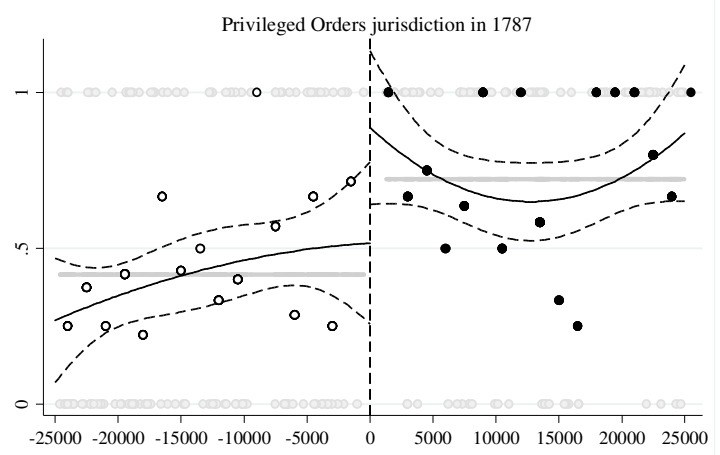

Distance to the frontier in meters (Former Kingdom of Granada in negative values)

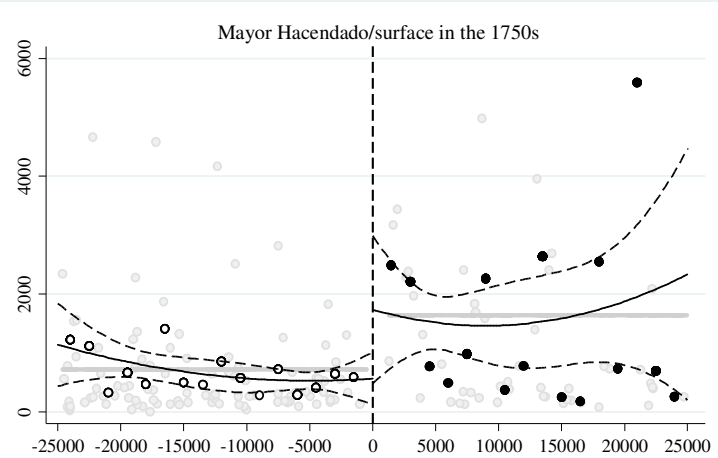

Distance to the frontier in meters (Former Kingdom of Granada in negative values)

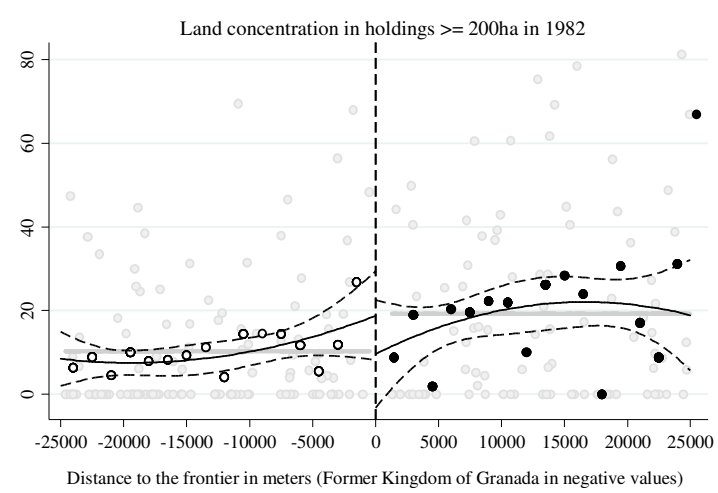

Distance to the frontier in meters (Former Kingdom of Granada in negative values)

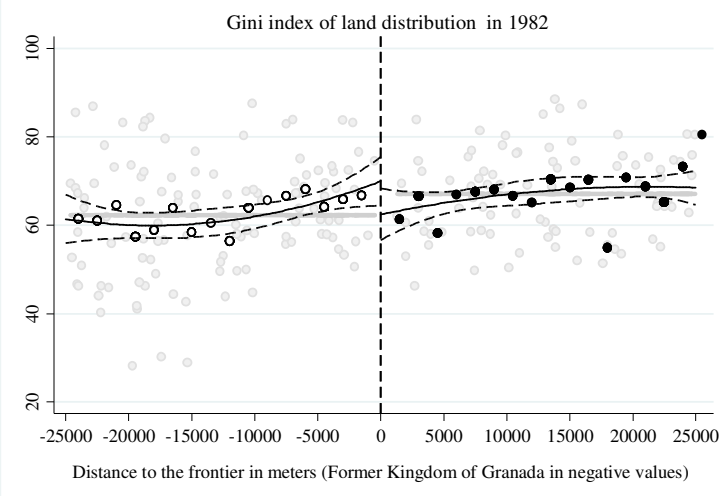

Figure 5. One-Dimensional RDD graphs in distance to the frontier

Notes: Black lines represent $90 \%$ confidence intervals for the quadratic polynomial in distance to the frontier. Gray lines indicate the global average value on each side of the frontier. Dots show the local average of the variable for municipalities in $1,5 \mathrm{~km}$ bins of their distance to the frontier. The actual values for each municipality are represented through light grey dots. 


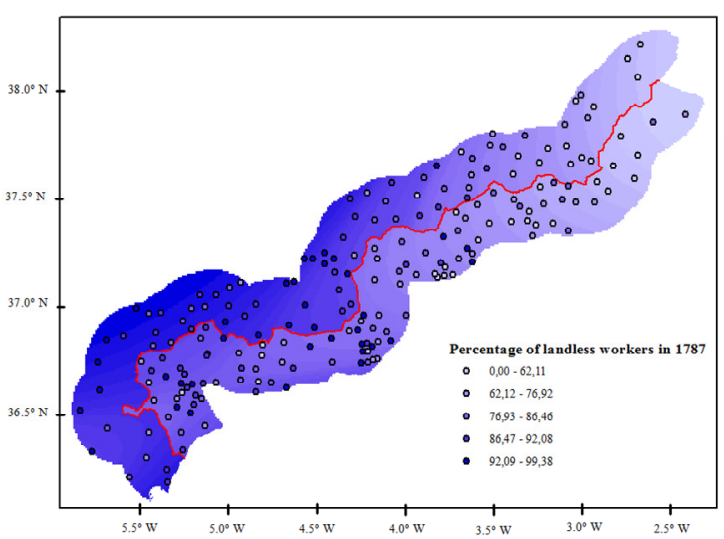

(a) Landless workers in 1787

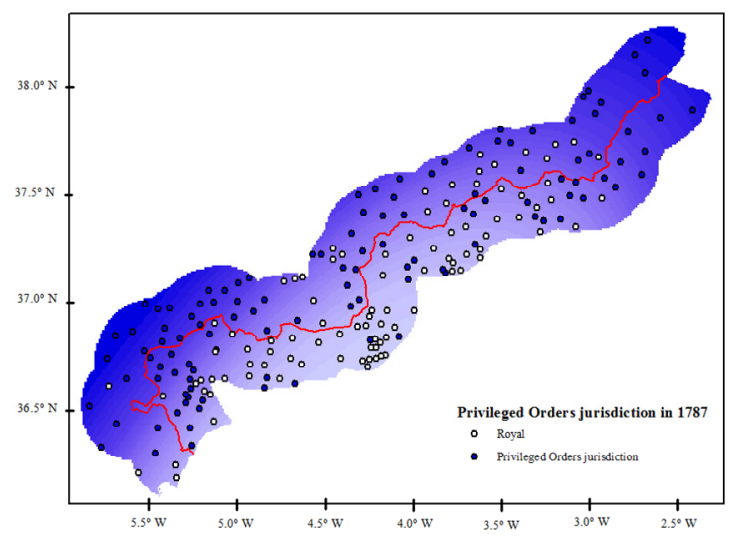

(c) Privileged Orders jurisdiction in 1787

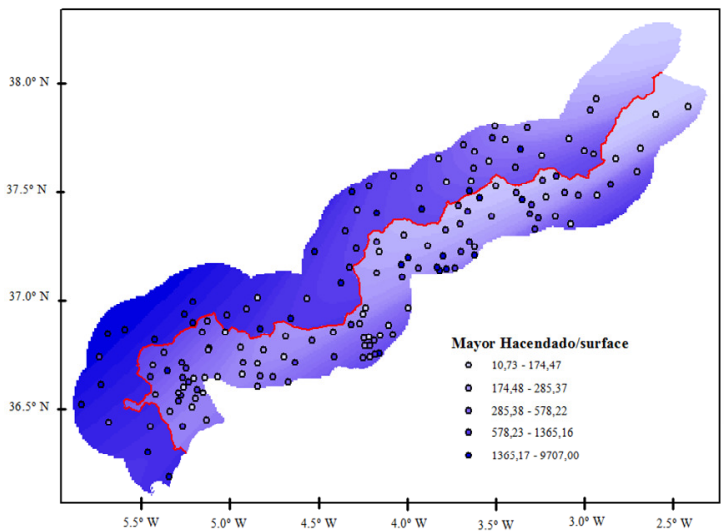

(b) Mayor Hacendado/surface in the $1750 \mathrm{~s}$

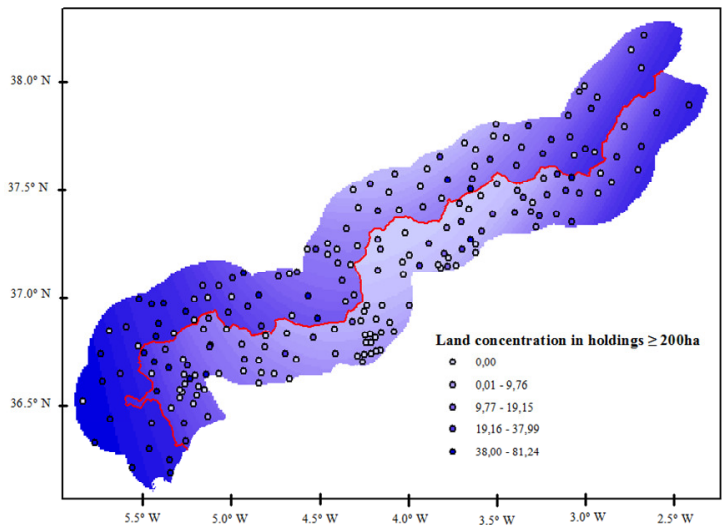

(d) Land concentration in holdings $\geq 200$ ha in 1982

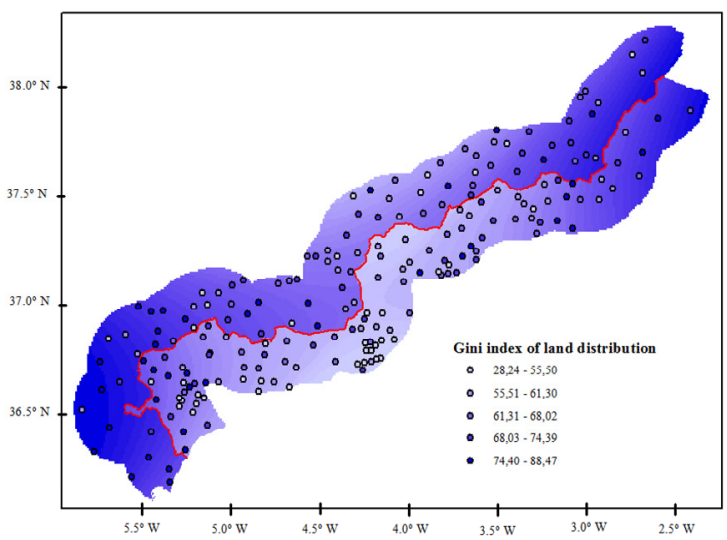

(e) Gini index of land distribution in 1982

Figure 6- Two-Dimensional RDD graphs in latitude and longitude

Notes: Dots represent the municipality values for the outcome variables, with each data point being located in the municipality centroid. The background color represents the predicted values for a 1-km grid, from a regression on a quadratic polynomial in latitude-longitude and the Castilian dummy, with a darker color indicating a higher predicted value. 